medRxiv preprint doi: https://doi.org/10.1101/2021.02.03.21251076; this version posted June 30, 2021. The copyright holder for this preprint (which was not certified by peer review) is the author/funder, who has granted medRxiv a license to display the preprint in perpetuity.

It is made available under a CC-BY-NC-ND 4.0 International license.

\title{
Title: Lifetime depression and age-related changes in body composition, cardiovascular function, grip strength and lung function: sex-specific analyses in the UK Biobank
}

Short title: Age-related physiological changes in lifetime depression

Authors: Julian Mutz ${ }^{1 *}$ and Cathryn M. Lewis ${ }^{1,2}$

\section{Affiliations:}

1. Social, Genetic and Developmental Psychiatry Centre, Institute of Psychiatry, Psychology \& Neuroscience, King’s College London, London, Greater London, SE5 8AF, United Kingdom.

2. Department of Medical and Molecular Genetics, Faculty of Life Sciences \& Medicine, King's College London, London, Greater London, SE1 9RT, United Kingdom.

\section{"Corresponding author:}

Julian Mutz; Social, Genetic and Developmental Psychiatry Centre, Institute of Psychiatry, Psychology \& Neuroscience, King’s College London; Memory Lane, London, SE5 8AF, United Kingdom. Email:

julian.mutz@gmail.com.

Keywords: Ageing; Body composition; Cardiovascular function; Depression; Grip strength; Lung function 
medRxiv preprint doi: https://doi.org/10.1101/2021.02.03.21251076; this version posted June 30, 2021. The copyright holder for this preprint (which was not certified by peer review) is the author/funder, who has granted medRxiv a license to display the preprint in perpetuity.

It is made available under a CC-BY-NC-ND 4.0 International license.

\section{Abstract}

Individuals with depression, on average, die prematurely, have high levels of physical comorbidities and may experience accelerated biological ageing. A greater understanding of age-related changes in physiology could provide novel biological insights that may help inform strategies to mitigate excess mortality in depression. We used generalised additive models to examine age-related changes in 15 cardiovascular, body composition, grip strength and lung function measures, comparing males and females with a lifetime history of depression to healthy controls. The main dataset included 342,393 adults (mean age $=55.87$ years, $\mathrm{SD}=8.09 ; 52.61 \%$ females). We found statistically significant casecontrol differences for most physiological measures. There was some evidence that age-related changes in body composition, cardiovascular function, lung function and heel bone mineral density followed different trajectories in depression. These differences did not uniformly narrow or widen with age and differed by sex. For example, BMI in female cases was $1.1 \mathrm{~kg} / \mathrm{m}^{2}$ higher at age 40 and this difference narrowed to $0.4 \mathrm{~kg} / \mathrm{m}^{2}$ at age 70 . In males, systolic blood pressure was $1 \mathrm{mmHg}$ lower in depression cases at age 45 and this difference widened to $2.5 \mathrm{mmHg}$ at age 65 . These findings suggest that targeted screening for physiological function in middle-aged and older adults with depression is warranted to potentially mitigate excess mortality. 
medRxiv preprint doi: https://doi.org/10.1101/2021.02.03.21251076; this version posted June 30, 2021. The copyright holder for this preprint (which was not certified by peer review) is the author/funder, who has granted medRxiv a license to display the preprint in perpetuity. It is made available under a CC-BY-NC-ND 4.0 International license .

\section{Introduction}

3 Individuals with mental disorders, on average, die prematurely [1] and have high levels of physical comorbidities [2].

4 Although it is almost universally accepted that health deteriorates as part of the normal ageing process, there is

5 substantial variation in ageing trajectories [3]. Up to a third of older adults experience depression and in many cases

6 show greater levels of functional decline and cognitive impairment [4].

8 To better understand the heterogeneity in ageing trajectories, it would be useful to objectively assess whether groups or 9 individuals deviate from 'normal' age-related changes. To date, no single biological marker that fully captures the ageing 10 process has been discovered, although several candidate measures such as telomere attrition have been described [5]. The 11 measurement of blood-based biomarkers such as leukocyte telomere length is minimally invasive, relatively costly and 12 time-consuming, especially at population scale. Magnetic resonance imaging, for instance used to derive estimates of 13 brain age [6], is costly and less accessible. Physiological measures such as hand-grip strength can be easily obtained, 14 provide reliable information about age-related functional decline and predict morbidity and mortality risk [7-9].

16 Several studies have examined age-related variation in these measures [10-12]. However, less is known about the ageing 17 trajectories of individuals with depression and whether similar patterns are observed across different physiological

18 measures. A deeper understanding of age-related changes in physiology in individuals with depression might provide

19 insights into the premature mortality observed in mental disorders and could point towards potential targets for

20 prevention or intervention of accelerated ageing [13].

22 The aim of this study was to examine associations between age and multiple physiological measures, and to test for 23 differences in these measures between middle-aged and older adults with a lifetime history of depression and healthy 24 controls across age. Given major sex differences in physiology, age-related diseases and life expectancy [14], and in 25 prevalence of depression [15], analyses were conducted separately in males and females. In a separate study, we have 26 examined age-related changes in physiology in bipolar disorder [16].

28 Using data from up to $\sim 342,000$ UK Biobank participants aged 37-73, the following research questions were examined

29 for each physiological measure assessed during the baseline assessment: Are there average differences between males

30 and females with lifetime depression and healthy controls? Do age-related changes differ between males and females

$31 \quad$ with lifetime depression and healthy controls? 
medRxiv preprint doi: https://doi.org/10.1101/2021.02.03.21251076; this version posted June 30, 2021. The copyright holder for this preprint (which was not certified by peer review) is the author/funder, who has granted medRxiv a license to display the preprint in perpetuity. It is made available under a CC-BY-NC-ND 4.0 International license .

\section{Results}

\section{Study population}

35 Of the 502,521 UK Biobank participants, 392,467 (78.1\%) individuals had complete data on all covariates. We yielded 36 an analytical sample of 342,393 adults after excluding individuals who did not meet our inclusion criteria or whose

37 lifetime depression status could not be determined. Sample sizes for physiological measures that were available in 38 subsets of the UK Biobank population ranged from 120,843 to 224,805 participants (Figure 1).

\section{Sample characteristics}

41 The average age of participants in our main dataset was 55.87 years $(\mathrm{SD}=8.09)$ and $52.61 \%$ of participants were

42 female. About $22.25 \%$ of participants $(n=87,339)$ met criteria for lifetime depression, $64.43 \%(n=56,276)$ of whom

43 were female. Descriptive statistics and density plots of the physiological measures stratified by sex and lifetime

44 depression status are presented in Table 1 and Supplement 5, respectively. Descriptive statistics of the covariates are 45 presented in Supplement 6.

\section{$47 \quad$ Sex differences}

48 We found moderate to large sex differences across all physiological measures. Female participants, on average, had

49 lower hand-grip strength, systolic and diastolic blood pressure, BMI, fat-free mass, waist-hip ratio, peak expiratory flow,

$50 \quad \mathrm{FEV}_{1}$, forced vital capacity, heel bone mineral density and arterial stiffness than males. Their pulse rate, body fat

51 percentage, fat mass and $\mathrm{FEV}_{1} / \mathrm{FVC}$ ratio were higher than in males (Table 2).

\section{Case-control differences}

54 We also found statistically significant differences between individuals with lifetime depression and healthy controls for

55 most measures. Females with lifetime depression, on average, had lower hand-grip strength and lower blood pressure.

56 Their pulse rate, BMI, body fat percentage, fat mass, fat-free mass, waist-hip ratio, peak expiratory flow, $\mathrm{FEV}_{1}$, forced

57 vital capacity and $\mathrm{FEV}_{1} / \mathrm{FVC}$ ratio were higher compared to healthy controls. We did not find evidence of differences in 58 heel bone mineral density or arterial stiffness between female cases and controls. Males with lifetime depression had

59 lower hand-grip strength, blood pressure, peak expiratory flow, $\mathrm{FEV}_{1}$, forced vital capacity and heel bone mineral

60 density, while their pulse rate, BMI, body fat percentage, fat mass, fat-free mass and waist-hip ratio were higher. We did

61 not find evidence that the $\mathrm{FEV}_{1} / \mathrm{FVC}$ ratio or arterial stiffness differed between males with lifetime depression and

62 healthy controls. The differences between individuals with lifetime depression and healthy controls were small, with the 
medRxiv preprint doi: https://doi.org/10.1101/2021.02.03.21251076; this version posted June 30, 2021. The copyright holder for this preprint (which was not certified by peer review) is the author/funder, who has granted medRxiv a license to display the preprint in perpetuity.

It is made available under a CC-BY-NC-ND 4.0 International license .

largest effect size corresponding to a standardised mean difference of 0.16 (95\% CI $0.15-0.17)$ for fat mass in females

64 (Table 3).

Age-related physiological changes

Results from the unadjusted GAMs suggested that hand-grip strength, fat-free mass, lung function and heel bone mineral density declined with age, while systolic blood pressure, body fat percentage, fat mass, waist-hip ratio and arterial stiffness increased with age. Non-linear associations with age were most evident for diastolic blood pressure, pulse rate and BMI. For example, diastolic blood pressure increased until about age 55 and decreased thereafter. BMI increased with age until participants were in their mid to late 50s and plateaued thereafter, except in healthy females where BMI increased until age 70 (Figure 2-3).

\section{Case-control differences in age-related physiological changes}

75 Age-related changes in blood pressure, pulse rate, body composition and heel bone mineral density followed distinct trajectories in females with lifetime depression and healthy controls (Figure 4). There was also evidence of differences in age-related changes hand-in grip strength, blood pressure, pulse rate, lung function and heel bone mineral density between males with lifetime depression and healthy controls (Figure 5).

In females, we obtained similar results after adjustment for covariates, although differences between cases and controls were attenuated and there was greater overlap in the trajectories of pulse rate, lung function and heel bone mineral density. We found no evidence that age-related changes in arterial stiffness differed between female cases and controls (Supplement 7A). We also obtained similar results after adjustment for covariates in males, with some attenuation of differences between cases and controls (Supplement 7B). The formal statistical tests for differences in age-related changes in hand-grip strength and heel bone mineral density were no longer statistically significant, although age-related changes in forced vital capacity and $\mathrm{FEV}_{1}$ differed between male cases and controls.

\section{Sensitivity analyses}

89 Case-control numbers for the sensitivity analyses are presented in Supplement $8 \mathrm{~A}$. We retained between $35.15 \%$ to

$9045.97 \%$ of cases and $100 \%$ of controls in the analyses in which cases included only those with lifetime depression

91 according to at least two different measures. In the analyses in which we restricted our sample to participants with

92 lifetime depression status assessed using the CIDI-SF, we retained between $24.69 \%$ to $40.67 \%$ of cases and between 
medRxiv preprint doi: https://doi.org/10.1101/2021.02.03.21251076; this version posted June 30, 2021. The copyright holder for this preprint (which was not certified by peer review) is the author/funder, who has granted medRxiv a license to display the preprint in perpetuity.

It is made available under a CC-BY-NC-ND 4.0 International license .

95 We found similar results when we applied more stringent criteria for lifetime depression. Average differences between

96 female cases and controls were slightly larger for all physiological measures. In males, differences were also larger,

97 except that there was no evidence of differences in lung function between cases and controls (Supplement 8B). Most

98 results were also similar when we restricted our analyses to individuals with lifetime depression status assessed using the

99 CIDI-SF. In females, differences were slightly larger, except for hand-grip strength, and there was no evidence of

100 differences in diastolic blood pressure. In males, there was no evidence that hand-grip strength or diastolic blood

101 pressure differed between cases and controls, and differences in lung function measures were reversed (although there

102 was no evidence of differences in peak expiratory flow or the $\mathrm{FEV}_{1} / \mathrm{FVC}$ ratio). Average differences in body

103 composition, systolic blood pressure and pulse rate were slightly larger, while differences in heel bone mineral density

104 were slightly smaller (Supplement 8B).

105

106 Differences in age-related changes in physiological measures between female cases and controls were similar to those

107 observed in our main analyses (Supplement 8C). There was less evidence that age-related changes in systolic blood

108 pressure differed between males with lifetime depression according to CIDI-SF and healthy controls. There was also

109 some evidence that age-related changes in body composition followed slightly different trajectories in males with

110 lifetime depression according to CIDI-SF, and there was more overlap in the lung function trajectories (Supplement 8D). 
medRxiv preprint doi: https://doi.org/10.1101/2021.02.03.21251076; this version posted June 30, 2021. The copyright holder for this preprint (which was not certified by peer review) is the author/funder, who has granted medRxiv a license to display the preprint in perpetuity. It is made available under a CC-BY-NC-ND 4.0 International license .

\section{Discussion}

112 We used data from the UK Biobank to examine differences in 15 physiological measures, between males and females,

113 and between lifetime depression cases and healthy controls. The large sample size enabled us to highlight subtle

114 differences between cases and controls, with heterogenous findings from previous studies that were often limited by

115 small sample sizes. We demonstrate that case-control differences for several physiological measures vary by age,

116 providing additional insights into the heterogeneity in ageing trajectories observed in individuals with a lifetime history

117 of depression.

119 Principal findings

120 We observed moderate to large sex differences across all physiological measures. We also found small but statistically

121 significant differences between lifetime depression cases and healthy controls for most measures. All physiological

122 measures varied with age, and we observed several differences between the trajectories of depression cases and controls.

123 Age-related changes in body composition differed between female cases and controls, while changes in cardiovascular

124 function differed between cases and controls of both sexes. There was some evidence of differences in the heel bone

125 mineral density trajectories of both sexes, although in males only prior to adjustment for covariates. We found some

126 evidence that age-related changes in lung function differed between male cases and controls after adjustment for

127 covariates. Differences between cases and controls did not uniformly narrow or widen with age. For example, BMI in

128 female cases was $1.1 \mathrm{~kg} / \mathrm{m}^{2}$ higher at age 40 and this difference narrowed to $0.4 \mathrm{~kg} / \mathrm{m}^{2}$ at age 70 . In male cases, systolic

129 blood pressure was $1 \mathrm{mmHg}$ lower at age 45 and this difference widened to $2.5 \mathrm{mmHg}$ at age 65 .

$131 \quad$ Findings in the context of other studies

133 Sex differences

134 We confirm previous research on sex differences in hand-grip strength [10, 17-19], blood pressure [20], pulse rate [21, 135 22], lung function [23-25], body fat percentage [26, 27], fat-free mass [26, 27] and waist-hip ratio [28]. Our finding that 136 BMI was higher in males confirms findings from a German study [28], although studies in US and Chinese adults found 137 no evidence of sex differences [26, 27]. The observation that fat mass was higher in females confirms findings from 138 Sweden [29] and the US [26], although research in Chinese adults found no evidence of sex differences [27]. Males had 139 higher heel bone mineral density, supporting previous studies of hand [30] and heel [31] bone mineral density. Our 140 finding that arterial stiffness was higher in males supports a review which found greater arterial stiffness in males until at 
medRxiv preprint doi: https://doi.org/10.1101/2021.02.03.21251076; this version posted June 30, 2021. The copyright holder for this preprint (which was not certified by peer review) is the author/funder, who has granted medRxiv a license to display the preprint in perpetuity. It is made available under a CC-BY-NC-ND 4.0 International license.

141 least age 60 [32]. However, most studies included in another systematic review found no evidence of sex differences

142 [33], and some studies found higher arterial stiffness in females [34-36].

144 Age-related physiological changes

145 Our findings confirm previous research on age-related changes in hand-grip strength [10, 18, 19], blood pressure [12, 20, $14637,38]$, fat mass [26, 29, 39], fat-free mass [26, 39, 40], waist-hip ratio [28], lung function [23-25, 41], bone mineral 147 density [30, 42] and arterial stiffness [21, 34]. In males, we observed a small increase in pulse rate until age 55 and a 148 decrease thereafter, similar to data from activity trackers in $>90,000$ US adults [22]. However, we found a slight decrease 149 in pulse rate in females until their mid 50s and an increase thereafter. Although we observed some increase in BMI with 150 age, comparable to results from Swedish cohorts [29], Chinese research found no evidence of age-related changes in 151 BMI [27]. Our finding that body fat percentage increased with age confirms previous studies [29, 40], although we found 152 limited evidence of a plateau or decrease before age 70 observed in previous research [26].

154 Sex differences in age-related physiological changes

155 We confirm previous studies on sex differences in age-related changes in hand-grip strength [17, 18], blood pressure [12, $15620,37]$, lung function [24, 41] and bone mineral density [30, 42]. In contrast to observations that pulse rate followed 157 parallel ageing trajectories in both sexes [22], we found changes in pulse rate in females were mirrored by inverse 158 changes in males.

160 Differences in BMI narrowed with age as BMI plateaued in males at age 50 and slightly decreased thereafter, while it 161 increased in females until at least age 65. Greater age-related increase in BMI in females has been observed previously 162 [29]. Body fat percentage followed similar trajectories with age in both sexes. However, research in Chinese adults 163 suggested that body fat percentage plateaued in males over 40 and continued to increase in females [27], while results 164 from the US showed that body fat percentage decreased in females and males over 55 and 65, respectively [26]. 165 Although Swedish data showed slightly greater age-related increase in fat mass in females [29], we found similar 166 trajectories in both sexes. Our finding that fat mass plateaued earlier in females confirms research in US adults [26]. 167 However, research in Chinese adults found that fat mass remained stable in males from age 40 but continued to increase 168 in females [27]. Our study did not support the finding that fat-free mass decreased earlier in females than in males [29]. 169 Fat-free mass decreased in both sexes, with steeper decline in males. Our finding that waist-hip ratio increased linearly 170 with age in females confirms observations from China [43], but we did not find that waist-hip ratio plateaued in males at age 50 and decreased thereafter. Instead, we found that waist-hip ratio continued to increase until age 70 . This increase 
medRxiv preprint doi: https://doi.org/10.1101/2021.02.03.21251076; this version posted June 30, 2021. The copyright holder for this preprint (which was not certified by peer review) is the author/funder, who has granted medRxiv a license to display the preprint in perpetuity.

It is made available under a CC-BY-NC-ND 4.0 International license.

172 attenuated at old age, in line with German research [28]. The difference between the trajectories of males and females

173 had an inverted U-shape, with the largest difference in waist-hip ratio between age 50 to 55.

175 We examined absolute changes in lung function. However, a review of longitudinal studies concluded that although there 176 was a steeper decline in absolute lung function in males, evidence of sex differences in relative decline in lung function 177 was limited [41]. Limited previous research examined sex differences in age-related changes in the $\mathrm{FEV}_{1} / \mathrm{FVC}$ ratio. We 178 found that the difference in the $\mathrm{FEV}_{1} / \mathrm{FVC}$ ratio narrowed with age, with some variation at the lower and upper age 179 range.

181 Finally, we found only limited evidence of a steeper age-related increase in arterial stiffness in males (in our study until 182 the age of 50) as suggested by previous studies [21,36], or that females over 65 had higher arterial stiffness than males 183 [32]. Sex differences in arterial stiffness narrowed between age 60 and 70.

\section{Case-control differences}

186 Our finding that hand-grip strength was lower in individuals with lifetime depression confirms previous research [44-47].

187 Although several studies found stronger associations between hand-grip strength and depression in females [44, 48, 49]

188 or no sex differences [45], we observed larger differences between male cases and controls. Results from the Northern

189 Finland 1966 birth cohort suggested that low hand-grip strength was associated with increased depressive symptoms only

190 in males [50], while in the Irish Longitudinal Study of Ageing higher hand-grip strength was associated with lower

191 incident depression only in females [44].

193 The finding that cases had lower blood pressure confirms results from the Norwegian HUNT study [51, 52]. Although

194 several studies found lower blood pressure in depression [51-54], other research found no evidence of differences in 195 blood pressure [55] and a meta-analysis found higher incident hypertension in depression [56]. A 2-year follow-up study 196 suggested that low blood pressure constitutes a risk factor for depression [57]. We confirmed previous analyses showing 197 higher pulse rate in depression [58-60].

199 All body composition measures were elevated in cases. A meta-analysis of observational studies found an increased risk 200 of obesity in depression [61], and findings from the 1958 British Birth Cohort found associations between depression and 201 both underweight and obesity [62]. Previous studies of BMI and depression yielded mixed results, including higher BMI 202 [63], lower BMI [64, 65], U-shaped association [66] or no association [67]. A Mendelian randomisation study suggested 
medRxiv preprint doi: https://doi.org/10.1101/2021.02.03.21251076; this version posted June 30, 2021. The copyright holder for this preprint (which was not certified by peer review) is the author/funder, who has granted medRxiv a license to display the preprint in perpetuity. It is made available under a CC-BY-NC-ND 4.0 International license.

204 hip ratio, including lower risk of depressive symptoms in older females with high waist-hip ratio [65] and associations 205 between depression and high waist-hip ratio [63, 69]. An analysis of UK Biobank participants found that females with 206 probable depression had higher waist-hip ratio than males [70], although other research found higher waist-hip ratio in 207 males with depression but not in females [71], or no evidence of an association with depressive symptoms [64]. Previous 208 research found no evidence of associations between depression and total fat or lean mass, although central fat mass and 209 lean mass were lower amongst older females with depression [72]. A Mendelian randomisation study suggested that fat 210 mass, but not fat-free mass, was a causal risk factor for depression [68]. Although we found higher body fat percentage 211 in cases, a recent analysis found associations between depression and higher body fat percentage only in females,

212 although participants were aged 90 years [73].

214 In contrast to results from the Netherlands Study of Anxiety and Depression (NESDA) which suggested that peak 215 expiratory flow was lower in females and higher in males with depression [74], we found higher peak expiratory flow in 216 female cases. Male cases had lower peak expiratory flow, although not across all analyses. We found similar results for $217 \mathrm{FEV}_{1}$, forced vital capacity and $\mathrm{FEV}_{1} / \mathrm{FVC}$ ratio. Differences between male cases and controls were usually not observed 218 in the sensitivity analyses, except that $\mathrm{FEV}_{1}$ and forced vital capacity were higher in the subset of male cases classified 219 according to CIDI-SF than in controls. Research in Germany found lower FEV $\mathrm{F}_{1}$ in depression but no evidence of 220 differences in forced vital capacity or $\mathrm{FEV}_{1} / \mathrm{FVC}$ ratio [75]. Data from a community-based cohort in Korea suggested 221 that $\mathrm{FEV}_{1}$, forced vital capacity and $\mathrm{FEV}_{1} / \mathrm{FVC}$ ratio were lower in depression, although only $\mathrm{FEV}_{1}$ remained lower after 222 adjustment for covariates [76]. However, a prospective study found that lower forced vital capacity and FEV 0.75 were 223 associated with more depressive symptoms at follow-up in middle aged and older males [77].

We found that heel bone mineral density was lower in male cases, consistent with most previous studies [78]. There was some evidence that heel bone mineral density was higher in female cases in sensitivity analyses, contrary to most previous studies. A meta-analysis of 14 studies showed that spine and hip bone mineral density were lower in depression, 228 especially in females [79]. One previous study suggested that heel bone mineral density was lower in female cases below 229 the age of 40 but not in older females [80], although another study found lower heel bone mineral density also in 230 postmenopausal females [81]. We did not find evidence that arterial stiffness differed between cases and controls. This 231 finding contrasts with most previous studies that found higher arterial stiffness in depression [82, 83], including a recent 232 UK Biobank study [84]. 
medRxiv preprint doi: https://doi.org/10.1101/2021.02.03.21251076; this version posted June 30, 2021. The copyright holder for this preprint (which was not certified by peer review) is the author/funder, who has granted medRxiv a license to display the preprint in perpetuity.

It is made available under a CC-BY-NC-ND 4.0 International license.

Case-control differences in age-related physiological changes

234 Hand-grip strength differences between female cases and controls were fairly stable across age, while generally

235 narrowing with age in males. To our knowledge, the only study that examined changes in hand-grip strength in

236 depression longitudinally found similar rates of decline in female cases and controls, in line with our findings. Contrary

237 to our study, the authors found no evidence that hand-grip strength decreased in male cases [85].

The HUNT study showed that prospective associations between depressive symptoms and changes in blood pressure were independent of age [51]. Findings from the Baltimore Longitudinal Study of Aging found associations between greater levels of depressive symptoms and lower diastolic blood pressure until age 45 , and attenuated age-related decline thereafter in females but not in males [86]. We found that case-control differences in systolic blood pressure increased with age. There was no evidence of a difference in diastolic blood pressure until participants were in their early to mid

24450 s, although diastolic blood pressure was lower in cases thereafter. This difference narrowed as participants approached age 70. To our knowledge, this is the first study to show that differences in pulse rate between cases and controls narrowed with age.

This is also the first study to examine age-related changes in body composition in cases compared to controls. Across these measures, we found that differences in body composition narrowed with age in females, while generally remaining constant in males. There were some inconsistencies in the sensitivity analyses with more stringent case definition. These analyses suggested an increasing difference in body fat percentage, a flat inverted U-shape for fat mass and fat-free mass, and some variation in the difference smooth for wait-hip ratio.

Results from the NESDA suggested a steeper decrease in peak expiratory flow in male cases during a 6-year follow-up, while rates of decline were similar in female cases and controls [85]. We also found some evidence of a steeper decrease in peak expiratory flow with age in male cases, although differences between female cases and controls remained stable. Rates of decline in the NESDA were similar in younger and older participants [85], concordant with our results showing an almost linear decrease in peak expiratory flow. While one previous study found a weak negative correlation between depressive symptoms and $\mathrm{FEV}_{1}$ only in participants older than 50 [76], our study is, to our knowledge, the first to examine case-control differences in ageing trajectories across multiple lung function measures. We found that the difference in $\mathrm{FEV}_{1}$ and forced vital capacity remained stable with age in females, with some variation in sensitivity analyses, while the difference widened with age in males, although not across all analyses. We did not find clear evidence of differences in the trajectories of $\mathrm{FEV}_{1} / \mathrm{FVC}$ ratio. 
medRxiv preprint doi: https://doi.org/10.1101/2021.02.03.21251076; this version posted June 30, 2021. The copyright holder for this preprint (which was not certified by peer review) is the author/funder, who has granted medRxiv a license to display the preprint in perpetuity. It is made available under a CC-BY-NC-ND 4.0 International license.

265 Differences in heel bone mineral density between cases and controls narrowed with age, approaching no difference in 266 males in their late 60s and in females in their mid 50s, with some evidence of higher bone mineral density in older 267 females. One previous study found lower heel bone mineral density in females with depression who were younger than 26840 but not in older females [80]. However, lower bone mineral density has also been found in postmenopausal females 269 with depression [87]. A meta-analysis of 23 studies found lower bone mineral density in the spine, hip and forearm in 270 premenopausal than in postmenopausal female cases compared to controls [88]. Our finding that differences in bone 271 mineral density narrowed with age differs from a meta-analysis of five longitudinal studies which suggested that 272 depression was associated with increased annual loss in hip and spine bone mineral density [79]. One study showed that 273 elderly females with higher levels of depressive symptoms had an age-adjusted mean total hip bone mineral density 274 decrease of $0.96 \%$ per year, compared to $0.69 \%$ in females with fewer symptoms [89]. Similar findings have been 275 observed in males [90]. However, a prospective study of premenopausal females found no evidence of decreasing bone 276 mineral density irrespective of depressive symptoms [91]. To our knowledge, this is the first study to examine 277 differences in age-related changes in arterial stiffness between cases and controls. While we did not find clear evidence 278 of different trajectories with age, there was some evidence that arterial stiffness was higher in female cases younger than 279 age 50.

281 Inconsistencies between studies could result from variation in sample characteristics, differences in assessment and 282 definition of depression, or medication use. For example, previous research found that after adjustment for depression, 283 antidepressant use was associated with lower spine bone mineral density in females but not in males [92], or that 284 depression was associated with lower systolic blood pressure, while antidepressant use was associated with higher 285 systolic and diastolic blood pressure [54]. Inconsistencies could also reflect differences in prevalence of specific 286 symptoms. For example, somatic/vegetative symptoms but not mood/cognitive symptoms were previously associated with higher waist-hip ratio [69].

Differences between cases and controls could reflect disease-related processes or poor underlying health status [93] occurring more frequently in cases. They could also result from biological mechanisms affecting depression and physiology (although a recent study did not find evidence of genetic correlations between depression and body composition [94]), or from treatment-related changes, for example lower bone mineral density due to antidepressant use [92]. Behavioural factors such as unhealthy lifestyles known to affect physiology (e.g., smoking and low levels of

295 in that depression is both cause and consequence of poor physiology [87]. Sex differences might be due to the relative 296 frequency of different symptoms experienced by males and females or differences in prevalence of comorbidities. 
medRxiv preprint doi: https://doi.org/10.1101/2021.02.03.21251076; this version posted June 30, 2021. The copyright holder for this preprint (which was not certified by peer review) is the author/funder, who has granted medRxiv a license to display the preprint in perpetuity. It is made available under a CC-BY-NC-ND 4.0 International license .

\section{Weaknesses of the study}

298 Our research inevitably has limitations. Although we briefly remarked on this above, our analyses provide limited 299 insights into the mechanism underpinning our results. The cross-sectional nature of our study presents additional 300 uncertainty about whether these findings reflect changes in physiology due to ageing or cohort-specific differences in 301 these measures and confounding factors. For example, previous research suggested that hand-grip strength is lower in 302 younger cohorts [19], which could result in underestimating age-related decline in our study. Research on frailty indices 303 provided evidence of stability across birth cohorts [95] as well as higher levels of frailty in more recent cohorts [96, 97].

304 The finding that some physiological differences narrowed with age could result from selection bias leading to older 305 participants with depression in our study being healthier, relative to their age group, than younger participants. Selection 306 bias resulting in healthier older adults participating in the UK Biobank at higher rates could also result in underestimating 307 age-related changes. Finally, some concerns remain about the validity and reliability of our definition of lifetime 308 depression [98]. To maximise the sample size available for our main analyses, we classified cases using multiple data 309 sources. However, these sources all have specific strengths and limitations, which have been discussed in detail 310 elsewhere [98-100]. For example, mental disorders are likely underreported in linked health records. Self-reports might 311 contain some level of misclassification because mental disorders are heterogenous in their presentation and have fuzzy 312 boundaries, although participants were asked to only report diagnoses made by health professionals. To address these 313 concerns, we conducted sensitivity analyses with more stringent case definition and found comparable results. Given that 314 mental disorders fluctuate throughout the life course, we examined lifetime depression, which includes single episode 315 and recurrent depression. Future studies could examine differences between single episode and recurrent depression as 316 well as changes in physiology in relation to current psychiatric status at a more fine-scale timespan longitudinally.

\section{Generalisability}

319 The overall response rate of the UK Biobank was low (5.5\%) and compared with non-responders, participants were 320 older, more often female, of higher socio-economic status and reported fewer health conditions compared with data from 321 a nationally representative survey [101]. An empirical investigation comparing the UK Biobank with data from 18 cohort 322 studies with conventional response rates found the direction of associations to be similar, although with differences in 323 magnitude [102]. There are additional concerns about the representativeness of individuals with mental disorders because 324 participation in research can be influenced by selection bias due to mental health [103]. Our findings might not 325 generalise to younger and older populations and conclusions are limited to adults between the ages of 37 to 73 .

326 Additional studies including children and adolescents as well as the elderly are needed. 
medRxiv preprint doi: https://doi.org/10.1101/2021.02.03.21251076; this version posted June 30, 2021. The copyright holder for this preprint (which was not certified by peer review) is the author/funder, who has granted medRxiv a license to display the preprint in perpetuity. It is made available under a CC-BY-NC-ND 4.0 International license .

\section{Implications}

328 The primary aim of this study was to examine differences in age-related physiological changes between individuals with

329 lifetime depression and healthy controls. Understanding age-related changes in physiology in individuals with depression

330 is of public health importance, given that variation in these measures is linked to morbidity, mortality and other

331 functional outcomes. The differences observed between cases and controls suggest that targeted screening for

332 physiological function in middle-aged and older adults with depression is warranted to potentially mitigate excess

333 mortality. Future studies aimed at further disentangling aetiology are needed to inform preventative and treatment

334 strategies. Interventions such as resistance training might help improve physiological health and reduce depressive

335 symptoms [104], although multiple factors associated with health status should be considered [105]. 
medRxiv preprint doi: https://doi.org/10.1101/2021.02.03.21251076; this version posted June 30, 2021. The copyright holder for this preprint (which was not certified by peer review) is the author/funder, who has granted medRxiv a license to display the preprint in perpetuity. It is made available under a CC-BY-NC-ND 4.0 International license .

\section{Methods}

\section{Study population}

338 The UK Biobank is a prospective study of $>500,000$ UK residents aged 37-73 at baseline, recruited between 2006-2010.

339 Details of the study rationale and design have been reported elsewhere [106]. Briefly, individuals registered with the UK

340 National Health Service (NHS) and living within a 25-mile ( 40 km) radius of one of 22 assessment centres were invited

341 to participate $(9,238,453$ postal invitations sent). Participants provided information on their sociodemographic

342 characteristics, health behaviours and medical history. They also underwent physical examination including height,

343 weight and blood pressure measurement, and had blood and urine samples taken. Linked hospital inpatient records are

344 available for most participants and primary care records are currently available for approximately half of participants. A

345 subset of 157,366 out of 339,092 invited participants (46\%) completed an online follow-up mental health questionnaire

346 (MHQ) between 2016-2017, covering 31\% of all participants.

$348 \quad$ Exposures

349 Age at baseline assessment was the primary explanatory variable.

Lifetime depression was assessed as part of the MHQ using a modified version of the depression module of the Composite International Diagnostic Interview Short Form (CIDI-SF) and defined according to DSM-5 criteria for major depressive disorder (Supplement 1) [107]. To achieve maximum coverage of the UK Biobank study, we also included in our definition of lifetime depression individuals who had reported during the nurse-led interview at baseline that a doctor had told them that they had depression (field 20002), participants who reported in response to a single-item question on the MHQ that a professional (doctors, nurse or person with specialist training such as psychologist or therapist) had diagnosed them with depression (field 20544), participants with a hospital inpatient record containing an ICD-10 code for depression (F32-F33; Supplement 2), participants with a primary care record containing a Read v2 or CTV3 code for depression (see [108] for diagnostic codes and data extraction procedures), and those who were classified as individuals with probable depression according to Smith et al. [109] based on additional questions that were introduced during the later stages of the baseline assessment (Supplement 3). We excluded individuals with any record of bipolar disorder or

Healthy controls were defined as individuals who did not meet our criteria for lifetime depression and did not have a record of other mental disorders: (i) no "schizophrenia", "mania/bipolar disorder/manic depression", "anxiety/panic 
medRxiv preprint doi: https://doi.org/10.1101/2021.02.03.21251076; this version posted June 30, 2021. The copyright holder for this preprint (which was not certified by peer review) is the author/funder, who has granted medRxiv a license to display the preprint in perpetuity.

It is made available under a CC-BY-NC-ND 4.0 International license.

reported during the nurse-led interview at baseline (field 20002); (ii) no mental disorders reported in response to the single-item question on the MHQ (field 20544); (iii) no self-reported current psychotropic medication use at baseline (Supplement 4) [100]; (iv) no linked hospital inpatient record that contained any ICD-10 Chapter V code except organic causes or substance use (F20-F99); (v) no primary care record containing a diagnostic code for mental disorders [108]; (vi) not classified as individual with probable bipolar disorder according to Smith et al. [109]; (vi) no Patient Health

372 Questionnaire-9 (PHQ-9) sum score of $\geq 5$, which was assessed as part of the MHQ.

\section{Outcomes}

375 We examined 15 continuous physiological measures that were obtained at the baseline assessment, including maximal 376 hand-grip strength, systolic and diastolic resting blood pressure, resting pulse rate, body mass index (BMI), waist-hip 377 ratio, fat mass, fat-free mass, body fat percentage, peak expiratory flow, forced vital capacity (FVC), forced expiratory 378 volume in one second $\left(\mathrm{FEV}_{1}\right), \mathrm{FVC} / \mathrm{FEV}_{1}$ ratio, heel bone mineral density and arterial stiffness.

\section{Physiological measures}

381 All physiological measures were collected by certified healthcare technicians or nurses using a direct data entry system.

382 Participants were asked to remove any outer garments, shoes, socks or tights. The assessment lasted about 10-15

383 minutes.

385 Hand-grip strength

386 Hand-grip strength in whole kilogram force units was measured using a Jamar J00105 hydraulic hand dynamometer (measurement range 0-90 kg). Participants were asked to sit upright in a chair and place their forearms on armrests. The dynamometer handle was set to the second incremental slot or, in participants with very large hands, moved to the third slot. Participants kept their elbow adjacent to their side and bent to a $90^{\circ}$ angle with their thumb facing upward. A maximal score was obtained from each participant's right and left hand. We used the maximal grip strength of the participant's self-reported dominant hand. If no data on handedness were available, we used the highest value of both

392 hands. This variable has been used previously in UK Biobank research [110], although other studies have used the 393 highest value of left and right hand [111] or calculated the average grip strength from both hands [9]. We used absolute 394 units because these are the simplest to use in risk assessment. A previous UK Biobank study found no evidence of 395 differences in mortality or disease incidence prediction when grip strength was expressed in absolute terms compared to when expressed relative to anthropometric traits (height, weight, fat-free mass and BMI) [9]. 
medRxiv preprint doi: https://doi.org/10.1101/2021.02.03.21251076; this version posted June 30, 2021. The copyright holder for this preprint (which was not certified by peer review) is the author/funder, who has granted medRxiv a license to display the preprint in perpetuity. It is made available under a CC-BY-NC-ND 4.0 International license .

Body composition

398 Weight measurements were obtained with a Tanita BC-418 MA body composition analyser, or, in individuals with pacemaker or females who reported that they were or might be pregnant, using a manual scale. Standing height was measured using a Seca 202 height measure. Body mass index (BMI) was calculated as weight divided by standing height squared $\left(\mathrm{kg} / \mathrm{m}^{2}\right)$. Waist and hip circumference in $\mathrm{cm}$ were measured using a Wessex non-stretchable sprung tape. Waistto-hip ratio was calculated by dividing waist circumference by hip circumference. Whole body fat mass and fat-free mass in $\mathrm{kg}$ and body fat percentage (measurement range 1-75\%) were estimated by electrical bio-impedance.

\section{Pulmonary function}

406 Volumetric measures of lung function were quantified using breath spirometry with a Vitalograph Pneumotrac 6800 407 following standard procedures. Participants were asked to record two to three blows, each lasting for at least six seconds, 408 within a period of approximately six minutes. The reproducibility of the first two blows was automatically compared 409 and, if acceptable (defined as a $\leq 5 \%$ difference in forced vital capacity (FVC) and forced expiratory volume in one 410 second $\left.\left(\mathrm{FEV}_{1}\right)\right)$, a third blow was not required. FVC in litres describes the maximum amount of air that can be exhaled 411 when blowing out as fast as possible after a deep breath. $\mathrm{FEV}_{1}$ in litres describes the amount of air that can be exhaled in 412 one second when blowing out as fast as possible. We used the derived best measure for both FVC and $\mathrm{FEV}_{1}$ which was 413 the maximum value from reproducible spirograms, in line with previous research [112]. Given that these measures are 414 affected by several factors unrelated to pulmonary function (e.g., effort and body size), we also calculated the ratio of

415 FEV $_{1}$ to FVC. Peak expiratory flow (PEF) in litres per minute represents a person's maximum speed of expiration. PEF

416 is determined by physiological factors such as lung volume and elasticity or expiratory muscle strength. It is used for 417 monitoring asthma and diagnosing chronic obstructive pulmonary disease. We calculated the average of all available 418 readings. Spirometry was not performed in participants who confirmed or were unsure that they had any of the following 419 contra-indications: chest infection in the last month (i.e., influenza, bronchitis, severe cold or pneumonia); history of a 420 detached retina; heart attack or surgery to eyes, chest or abdomen in the last three months; history of a collapsed lung; pregnancy in the 1st or 3rd trimester; currently on medication for tuberculosis.

Heel bone mineral density

424 Heel bone mineral density was estimated by quantitative ultrasound assessment of the calcaneus using a Sahara Clinical 425 Bone Sonometer. Participants were asked to sit with their back straight and had their left heel measured first.

426 Measurement of both heels was performed only during later stages of the baseline assessment. Measures of speed of sound in metres per second and broadband ultrasound attenuation (decibels/megahertz) were combined into a 
medRxiv preprint doi: https://doi.org/10.1101/2021.02.03.21251076; this version posted June 30, 2021. The copyright holder for this preprint (which was not certified by peer review) is the author/funder, who has granted medRxiv a license to display the preprint in perpetuity. It is made available under a CC-BY-NC-ND 4.0 International license .

428 quantitative ultrasound index. From this an estimate of heel bone mineral density in grams per $\mathrm{cm}^{2}$ was derived based on

429 the assumption that sound waves travel differently through denser bones.

\section{Cardiovascular measures}

432 Blood pressure, pulse rate and arterial stiffness (pulse wave velocity) were measured by trained nurses during a separate 433 stage of the baseline assessment.

Blood pressure

436 Seated systolic and diastolic resting blood pressure in millimetres of mercury $(\mathrm{mmHg})$ was measured twice using an

437 Omron 705 IT digital blood pressure monitor (measurement range 0-255 mmHg) following standard procedures.

438 Participants were asked to loosen or remove any restrictive clothing and put their arm on a desktop. Measurements were 439 taken from the left upper arm or, if impractical, from the right arm. If there was a problem with the measurement, it was 440 repeated. Three different cuff sizes were available and a Seca tape was used to determine the circumference of the 441 midpoint of the upper arm. If the largest cuff size was too small or the digital blood pressure monitor did not produce a 442 reading, a manual sphygmomanometer was used in conjunction with a stethoscope. A second measurement was taken at 443 least one minute after the first measure, following the same procedure. We used an average of the two readings to reduce 444 potential measurement error.

Pulse rate

447 Resting pulse rate in beats per minute was recorded during the blood pressure measurements using the Omron 705 IT 448 device or, exceptionally, a manual sphygmomanometer. We used an average of the two readings to reduce potential 449 measurement error.

Arterial stiffness

452 Arterial stiffness (vascular reactivity) is an independent predictor of cardiovascular risk and mortality that can be 453 measured rapidly, inexpensively, and without special training [113]. Resting pulse wave velocity was measured non454 invasively using finger photoplethysmography with a PulseTrace PCA2 infra-red sensor. The pulse waveform was 455 recorded over a period of 10-15 seconds, with the sensor clipped to the end of the index finger of the non-dominant hand 456 while the participant was sitting. If the waveform did not fill at least $2 / 3$ of the display of the device, or did not stabilize 457 within one minute, the measurement was repeated on a larger finger or on the thumb. The shape of the waveform is 458 directly related to the time it takes for the pulse wave to travel through the arterial tree in the lower body and to be 459 reflected back to the finger. The time between the peaks of the waveform (the pulse wave peak-to-peak time, i.e., the 
medRxiv preprint doi: https://doi.org/10.1101/2021.02.03.21251076; this version posted June 30, 2021. The copyright holder for this preprint (which was not certified by peer review) is the author/funder, who has granted medRxiv a license to display the preprint in perpetuity.

It is made available under a CC-BY-NC-ND 4.0 International license.

difference between the peak values of direct and reflected components) was divided by the participant's height to obtain the arterial stiffness index in metres per second. A higher score on the index represents stiffer arteries. The method has been externally validated and is highly correlated with the gold-standard carotid-femoral pulse wave velocity [114].

\section{Exclusion criteria}

465 Participants for whom their genetic sex, inferred from the relative intensity of biological markers on the $\mathrm{Y}$ and $\mathrm{X}$ chromosomes, and self-reported sex did not match were excluded. Participants with missing data for any covariates or who responded "do not know" or "prefer not to answer" were excluded from all analyses.

\section{Covariates}

470 Covariates included ethnicity (White, Asian, Black, Chinese, Mixed-race or other), gross annual household income $471(<£ 18,000, £ 18,000-30,999, £ 31,000-51,999, £ 52,000-100,000$ or $>£ 100,000)$, physical activity (number of days per week spent walking, engaging in moderate-intensity physical activity and engaging in vigorous-intensity physical activity for $\geq 10$ minutes continuously), smoking status (never, former or current), alcohol intake frequency (never, special occasions only, one to three times a month, once or twice a week, three or four times a week or daily or almost daily), sleep duration (hours per day) and, for cardiovascular measures, current use of antihypertensive medications at baseline (yes/no). See our previous publication [105] for further details on these variables.

\section{Statistical analyses}

479 All analyses, except the sensitivity analyses, were pre-specified prior to inspection of the data (preregistration: osf.io/pc76g) and algorithms were tested on simulated data. Statistical analyses were conducted using R (version 3.6.0).

Sample characteristics were summarised using means and standard deviations or counts and percentages. We also present the number of individuals who met our criteria for lifetime depression and healthy control. Kernel density plots of all physiological measures stratified by lifetime depression case status are presented separately for males and females.

Differences between the sexes and between cases and controls were estimated using standardised mean differences $( \pm$ $95 \%$ confidence intervals).

We examined the relationship between each physiological measure and age using generalised additive models (GAMs) with the 'mgcv' package in R [115]. Each measure was modelled against a penalised regression spline function of age with separate smooths for individuals with lifetime depression and healthy controls. GAMs are flexible modelling approaches that allow for the relationship between an outcome variable and a continuous exposure to be represented by a 
medRxiv preprint doi: https://doi.org/10.1101/2021.02.03.21251076; this version posted June 30, 2021. The copyright holder for this preprint (which was not certified by peer review) is the author/funder, who has granted medRxiv a license to display the preprint in perpetuity.

It is made available under a CC-BY-NC-ND 4.0 International license.

non-linear smooth curve while controlling for covariates. They are particularly useful if a linear model does not capture

493 key aspects of the relationship between variables and attempt to achieve maximum goodness-of-fit while maintaining

494 parsimony of the fitted curve to minimize overfitting. Smoothing parameters were selected using the restricted maximum

495 likelihood method and we used the default option of ten basis functions to represent smooth terms in each model.

497 Two models were fit for males and females separately:

- Unadjusted model: physiological measure $\sim$ lifetime depression $+\mathrm{s}$ (age, by lifetime depression).

- Adjusted model: physiological measure $\sim$ lifetime depression $+\mathrm{s}($ age, by lifetime depression $)+$ covariates

507 lifetime depression and healthy controls, we also fit, in separate analyses, models that included a reference smooth for

508 healthy controls and a difference smooth for individuals with lifetime depression compared to healthy controls. For these

509 analyses, lifetime depression status was coded as an ordered factor in R. If the difference smooth differs from zero,

510 individuals with lifetime depression and healthy controls follow a different trend with age.

512 Adjusted $p$-values were calculated using the p.adjust() command in $\mathrm{R}$ to account for multiple testing across each set of

513 analyses of the 15 physiological measures. Two methods were used: (1) Bonferroni and (2) Benjamini \& Hochberg

514 [116], all two-tailed, with $\alpha=.05$ and false discovery rate of $5 \%$, respectively.

516 To address potential concerns about the validity and reliability of our case definition, we conducted sensitivity analyses

517 in which we restricted the samples to (i) individuals with lifetime depression according to at least two different data

518 sources and (ii) individuals with lifetime depression status assessed using the CIDI-SF. These sensitivity analyses were

519 not preregistered. 
medRxiv preprint doi: https://doi.org/10.1101/2021.02.03.21251076; this version posted June 30, 2021. The copyright holder for this preprint (which was not certified by peer review) is the author/funder, who has granted medRxiv a license to display the preprint in perpetuity.

It is made available under a CC-BY-NC-ND 4.0 International license.

\section{Authorship contributions}

CML acquired the studentship funding, interpreted the findings and critically reviewed the manuscript. JM conceived the idea of the study, acquired the data, carried out the statistical analysis, interpreted the findings, wrote the manuscript and revised the manuscript for final submission. Both authors read and approved the final manuscript. JM had full access to all data used in this study and takes responsibility for the integrity of the data and the accuracy of the data analysis.

\section{Acknowledgments}

This research has been conducted using data from UK Biobank, a major biomedical database. This project made use of time on Rosalind HPC, funded by Guy's \& St Thomas' Hospital NHS Trust Biomedical Research Centre (GSTT-BRC), South London \& Maudsley NHS Trust Biomedical Research Centre (SLAM-BRC), and Faculty of Natural Mathematics $\&$ Science (NMS) at King's College London.

\section{Conflicts of Interest and Funding}

JM receives studentship funding from the Biotechnology and Biological Sciences Research Council (BBSRC) (ref: 2050702) and Eli Lilly and Company Limited. CML is part-funded by the National Institute for Health Research (NIHR) Maudsley Biomedical Research Centre at South London and Maudsley NHS Foundation Trust and King's College London. The views expressed are those of the authors and not necessarily those of the NHS, the NIHR or the Department of Health and Social Care. CML is a member of the Scientific Advisory Board of Myriad Neuroscience.

\section{Ethics}

Ethical approval for the UK Biobank study has been granted by the National Information Governance Board for Health and Social Care and the NHS North West Multicentre Research Ethics Committee (11/NW/0382). No project-specific ethical approval is needed. Data access permission has been granted under UK Biobank application 45514.

\section{Data sharing statement}

The data used are available to all bona fide researchers for health-related research that is in the public interest, subject to an application process and approval criteria. Study materials are publicly available online at http://www.ukbiobank.ac.uk.

\section{Supplementary material}

Supplementary information is available online. 
medRxiv preprint doi: https://doi.org/10.1101/2021.02.03.21251076; this version posted June 30, 2021. The copyright holder for this preprint (which was not certified by peer review) is the author/funder, who has granted medRxiv a license to display the preprint in perpetuity.

It is made available under a CC-BY-NC-ND 4.0 International license .

\section{References}

551 1. Plana-Ripoll O, Weye N, Momen NC, Christensen MK, Iburg KM, Laursen TM, McGrath JJ. Changes over

552 time in the differential mortality gap in individuals with mental disorders. JAMA Psychiatry. 2020; 77: 648-50.

553 2. Kessler RC, Berglund P, Demler O, Jin R, Koretz D, Merikangas KR, Rush AJ, Walters EE, Wang PS. The

554 epidemiology of major depressive disorder: results from the National Comorbidity Survey Replication (NCS-R). JAMA. $555 \quad 2003 ; 289: 3095-105$.

556 3. Daskalopoulou C, Koukounari A, Wu Y-T, Terrera GM, Caballero FF, de la Fuente J, Tyrovolas S,

557 Panagiotakos DB, Prince M, Prina M. Healthy ageing trajectories and lifestyle behaviour: the Mexican Health and Aging 558 Study. Scientific Reports. 2019; 9: 1-10.

559 4. Wilkinson P, Ruane C, Tempest K. Depression in older adults. The BMJ. 2018; $363:$ k4922.

560 5. López-Otín C, Blasco MA, Partridge L, Serrano M, Kroemer G. The hallmarks of aging. Cell. 2013; 153: 1194561217.

562 6. Cole JH, Franke K. Predicting age using neuroimaging: innovative brain ageing biomarkers. Trends in 563 Neurosciences. 2017; 40: 681-90.

$5647 . \quad$ Veronese N, Stubbs B, Fontana L, Trevisan C, Bolzetta F, Rui MD, Sartori L, Musacchio E, Zambon S, Maggi

565 S, Perissinotto, E, Corti, MC, Crepaldi, G, et al. A comparison of objective physical performance tests and future

566 mortality in the elderly people. Journals of Gerontology Series A: Biomedical Sciences and Medical Sciences. 2017; 72:

$567 \quad 362-8$

568 8. Celis-Morales CA, Welsh P, Lyall DM, Steell L, Petermann F, Anderson J, Iliodromiti S, Sillars A, Graham N, 569 Mackay DF, Pell JP, Gill, JMR, Sattar N, et al. Associations of grip strength with cardiovascular, respiratory, and cancer 570 outcomes and all cause mortality: prospective cohort study of half a million UK Biobank participants. The BMJ. 2018; $571 \quad 361: \mathrm{k} 1651$.

$5729 . \quad$ Ho FK, Celis-Morales CA, Petermann-Rocha F, Sillars A, Welsh P, Welsh C, Anderson J, Lyall DM, Mackay 573 DF, Sattar N, Gill, JMR, Pell JP, Gray SR. The association of grip strength with health outcomes does not differ if grip 574 strength is used in absolute or relative terms: a prospective cohort study. Age and Ageing. 2019; 48: 684-91.

575 10. Dodds RM, Syddall HE, Cooper R, Benzeval M, Deary IJ, Dennison EM, Der G, Gale CR, Inskip HM, Jagger

576 C, Kirkwood TB, Lawlor DA, Robinson SM, et al. Grip strength across the life course: normative data from twelve

577 British studies. PloS One. 2014; 9: e113637.

578 11. Cheng S, Xanthakis V, Sullivan LM, Vasan RS. Blood pressure tracking over the adult life course: patterns and 579 correlates in the Framingham heart study. Hypertension. 2012; 60: 1393-9. 
medRxiv preprint doi: https://doi.org/10.1101/2021.02.03.21251076; this version posted June 30, 2021. The copyright holder for this preprint (which was not certified by peer review) is the author/funder, who has granted medRxiv a license to display the preprint in perpetuity.

It is made available under a CC-BY-NC-ND 4.0 International license.

580 12. Ji H, Kim A, Ebinger JE, Niiranen TJ, Claggett BL, Merz CNB, Cheng S. Sex differences in blood pressure

581 trajectories over the life course. JAMA Cardiology. 2020; 5: 19-26.

582 13. Wolkowitz OM. Accelerated biological aging in serious mental disorders. World Psychiatry. 2018; 17: 144-5.

583 14. Austad SN, Bartke A. Sex differences in longevity and in responses to anti-aging interventions: a mini-review.

584 Gerontology. 2016; 62: 40-6.

585 15. McCarthy MM, Nugent BM, Lenz KM. Neuroimmunology and neuroepigenetics in the establishment of sex

586 differences in the brain. Nature Reviews Neuroscience. 2017; 18: 471-84.

587 16. Mutz J, Young AH, Lewis CM. Age-related changes in physiology in individuals with bipolar disorder.

588 medRxiv. 2021.

589 17. Cooper R, Hardy R, Sayer AA, Ben-Shlomo Y, Birnie K, Cooper C, Craig L, Deary IJ, Demakakos P, Gallacher

590 J, McNeill G, Martin RM, Starr JM, et al. Age and gender differences in physical capability levels from mid-life

591 onwards: the harmonisation and meta-analysis of data from eight UK cohort studies. PloS One. $2011 ; 6$ : e27899.

592 18. Keevil VL, Hayat S, Dalzell N, Moore S, Bhaniani A, Luben R, Wareham NJ, Khaw K-T. The physical

593 capability of community-based men and women from a British cohort: the European Prospective Investigation into

594 Cancer (EPIC)-Norfolk study. BMC Geriatrics. 2013; 13: 93.

595 19. Beller J, Miething A, Regidor E, Lostao L, Epping J, Geyer S. Trends in grip strength: Age, period, and cohort

596 effects on grip strength in older adults from Germany, Sweden, and Spain. SSM-Population Health. 2019 ; 9: 100456.

597 20. Burt VL, Whelton P, Roccella EJ, Brown C, Cutler JA, Higgins M, Horan MJ, Labarthe D. Prevalence of 598 hypertension in the US adult population: results from the Third National Health and Nutrition Examination Survey, 599 1988-1991. Hypertension. 1995; 25: 305-13.

600 21. AlGhatrif M, Strait JB, Morrell CH, Canepa M, Wright J, Elango P, Scuteri A, Najjar SS, Ferrucci L, Lakatta

601 EG. Longitudinal trajectories of arterial stiffness and the role of blood pressure: the Baltimore Longitudinal Study of 602 Aging. Hypertension. 2013; 62: 934-41.

603 22. Quer G, Gouda P, Galarnyk M, Topol EJ, Steinhubl SR. Inter-and intraindividual variability in daily resting 604 heart rate and its associations with age, sex, sleep, BMI, and time of year: retrospective, longitudinal cohort study of 60592,457 adults. Plos One. 2020; 15: e0227709.

606 23. Liao SY, Lin X, Christiani DC. Occupational exposures and longitudinal lung function decline. American 607 Journal of Industrial Medicine. 2015; 58: 14-20.

608 24. Nunn A, Gregg I. New regression equations for predicting peak expiratory flow in adults. The BMJ. 1989; 298: 609 1068-70. 
medRxiv preprint doi: https://doi.org/10.1101/2021.02.03.21251076; this version posted June 30, 2021. The copyright holder for this preprint (which was not certified by peer review) is the author/funder, who has granted medRxiv a license to display the preprint in perpetuity.

It is made available under a CC-BY-NC-ND 4.0 International license.

610 25. van Oostrom SH, Engelfriet PM, Verschuren WM, Schipper M, Wouters IM, Boezen M, Smit HA, Kerstjens

611 HA, Picavet HSJ. Aging-related trajectories of lung function in the general population-The Doetinchem Cohort Study.

612 PloS One. 2018; 13: e0197250.

613 26. Li C, Ford ES, Zhao G, Balluz LS, Giles WH. Estimates of body composition with dual-energy X-ray

614 absorptiometry in adults. The American Journal of Clinical Nutrition. 2009; 90: 1457-65.

615 27. He X, Li Z, Tang X, Zhang L, Wang L, He Y, Jin T, Yuan D. Age-and sex-related differences in body

616 composition in healthy subjects aged 18 to 82 years. Medicine. 2018; 97: e11152.

617 28. Frenzel A, Binder H, Walter N, Wirkner K, Loeffler M, Loeffler-Wirth H. The aging human body shape. NPJ

618 Aging and Mechanisms of Disease. 2020; 6: 1-15.

619 29. Larsson I, Lissner L, Samuelson G, Fors H, Lantz H, Näslund I, Carlsson L, Sjöström L, Bosaeus I. Body 620 composition through adult life: Swedish reference data on body composition. European Journal of Clinical Nutrition.

$6212015 ; 69: 837-42$.

622 30. Malkin I, Bigman G, Matias R, Kalichman L, Seibel M, Kobyliansky E, Livshits G. Age-related changes of

623 bone strength phenotypes: observational follow-up study of hand bone mineral density. Archives of Osteoporosis. 2006;

$624 \quad 1: 59-68$.

625 31. Ross RD, Shah RC, Leurgans SE, Buchman AS, Bennett DA. Association of heel bone mineral density with 626 incident disability and mortality in community-dwelling older adults. JBMR Plus. 2020; 4: e10390.

627 32. Merz AA, Cheng S. Sex differences in cardiovascular ageing. Heart. 2016; 102: 825-31.

628 33. Cecelja M, Chowienczyk P. Dissociation of aortic pulse wave velocity with risk factors for cardiovascular 629 disease other than hypertension: a systematic review. Hypertension. 2009; 54: 1328-36.

630 34. Mitchell GF, Parise H, Benjamin EJ, Larson MG, Keyes MJ, Vita JA, Vasan RS, Levy D. Changes in arterial 631 stiffness and wave reflection with advancing age in healthy men and women: the Framingham Heart Study.

632 Hypertension. 2004; 43: 1239-45.

633 35. Russo C, Jin Z, Palmieri V, Homma S, Rundek T, Elkind MS, Sacco RL, Di Tullio MR. Arterial stiffness and 634 wave reflection: sex differences and relationship with left ventricular diastolic function. Hypertension. $2012 ; 60$ : 362-8.

635 36. Coutinho T, Borlaug BA, Pellikka PA, Turner ST, Kullo IJ. Sex differences in arterial stiffness and ventricular636 arterial interactions. Journal of the American College of Cardiology. 2013; 61: 96-103.

637 37. Franklin SS, Gustin IV W, Wong ND, Larson MG, Weber MA, Kannel WB, Levy D. Hemodynamic patterns of 638 age-related changes in blood pressure: the Framingham Heart Study. Circulation. 1997; 96: 308-15.

639 38. Wolf-Maier K, Cooper RS, Banegas JR, Giampaoli S, Hense H-W, Joffres M, Kastarinen M, Poulter N, 640 Primatesta P, Rodríguez-Artalejo F. Hypertension prevalence and blood pressure levels in 6 European countries, Canada, 641 and the United States. JAMA. 2003; 289: 2363-9. 
medRxiv preprint doi: https://doi.org/10.1101/2021.02.03.21251076; this version posted June 30, 2021. The copyright holder for this preprint (which was not certified by peer review) is the author/funder, who has granted medRxiv a license to display the preprint in perpetuity.

It is made available under a CC-BY-NC-ND 4.0 International license.

39. Kyle UG, Genton L, Slosman DO, Pichard C. Fat-free and fat mass percentiles in 5225 healthy subjects aged 15 to 98 years. Nutrition. $2001 ; 17: 534-41$.

40. Jackson AS, Janssen I, Sui X, Church TS, Blair SN. Longitudinal changes in body composition associated with healthy ageing: men, aged 20-96 years. British Journal of Nutrition. 2012; 107: 1085-91.

41. Thomas ET, Guppy M, Straus SE, Bell KJ, Glasziou P. Rate of normal lung function decline in ageing adults: a systematic review of prospective cohort studies. BMJ open. 2019; 9: e028150.

42. Malkin I, Karasik D, Livshits G, Kobyliansky E. Modelling of age-related bone loss using cross-sectional data. Annals of Human Biology. 2002; 29: 256-70.

43. Qian X, Su C, Zhang B, Qin G, Wang H, Wu Z. Changes in distributions of waist circumference, waist-to-hip ratio and waist-to-height ratio over an 18-year period among Chinese adults: a longitudinal study using quantile regression. BMC Public Health. 2019; 19: 700.

44. McDowell CP, Gordon BR, Herring MP. Sex-related differences in the association between grip strength and depression: results from the Irish Longitudinal Study on Ageing. Experimental Gerontology. 2018; 104: 147-52.

45. Ashdown-Franks G, Stubbs B, Koyanagi A, Schuch F, Firth J, Veronese N, Vancampfort D. Handgrip strength and depression among 34,129 adults aged 50 years and older in six low-and middle-income countries. Journal of Affective Disorders. 2019; 243: 448-54.

46. Han K-M, Chang J, Yoon H-K, Ko Y-H, Ham B-J, Kim Y-K, Han C. Relationships between hand-grip strength, socioeconomic status, and depressive symptoms in community-dwelling older adults. Journal of Affective Disorders. 2019; 252: 263-70.

47. Volaklis K, Mamadjanov T, Meisinger C, Linseisen J. Association between muscular strength and depressive symptoms. Wiener Klinische Wochenschrift. 2019; 131: 255-64.

48. Veronese N, Stubbs B, Trevisan C, Bolzetta F, De Rui M, Solmi M, Sartori L, Musacchio E, Zambon S, Perissinotto E, Baggio G, Crepaldi G, Manzato E, et al. Poor physical performance predicts future onset of depression in elderly people: Progetto Veneto Anziani Longitudinal Study. Physical Therapy. 2017; 97: 659-68.

49. Smith L, White S, Stubbs B, Hu L, Veronese N, Vancampfort D, Hamer M, Gardner B, Yang L. Depressive symptoms, handgrip strength, and weight status in US older adults. Journal of Affective Disorders. 2018; 238: 305-10. 50. Suija K, Timonen M, Suviola M, Jokelainen J, Järvelin M-R, Tammelin T. The association between physical fitness and depressive symptoms among young adults: results of the Northern Finland 1966 birth cohort study. BMC Public Health. 2013; 13: 535.

51. Hildrum B, Mykletun A, Holmen J, Dahl AA. Effect of anxiety and depression on blood pressure: 11-year longitudinal population study. The British Journal of Psychiatry. 2008; 193: 108-13. 
medRxiv preprint doi: https://doi.org/10.1101/2021.02.03.21251076; this version posted June 30, 2021. The copyright holder for this preprint (which was not certified by peer review) is the author/funder, who has granted medRxiv a license to display the preprint in perpetuity.

It is made available under a CC-BY-NC-ND 4.0 International license.

67352

2. Hildrum B, Mykletun A, Stordal E, Bjelland I, Dahl AA, Holmen J. Association of low blood pressure with

674 anxiety and depression: the Nord-Trøndelag Health Study. Journal of Epidemiology \& Community Health. 2007; 61: 53-

6758.

676 53. Tikhonoff V, Hardy R, Deanfield J, Friberg P, Kuh D, Muniz G, Pariante CM, Hotopf M, Richards M.

677 Symptoms of anxiety and depression across adulthood and blood pressure in late middle age: the 1946 British birth

678 cohort. Journal of Hypertension. 2014; 32: 1590-99.

679 54. Licht CM, De Geus EJ, Seldenrijk A, Van Hout HP, Zitman FG, Van Dyck R, Penninx BW. Depression is

680 associated with decreased blood pressure, but antidepressant use increases the risk for hypertension. Hypertension. 2009;

$681 \quad 53: 631-8$

682 55. Shinn EH, Poston WSC, Kimball KT, St. Jeor ST, Foreyt JP. Blood pressure and symptoms of depression and 683 anxiety: a prospective study. American Journal of Hypertension. 2001; 14: 660-4.

684 56. Meng L, Chen D, Yang Y, Zheng Y, Hui R. Depression increases the risk of hypertension incidence: a meta685 analysis of prospective cohort studies. Journal of Hypertension. 2012; 30: 842-51.

686 57. Paterniti S, Verdier-Taillefer M-H, Geneste C, Bisserbe J-C, Alpérovitch A. Low blood pressure and risk of 687 depression in the elderly: a prospective community-based study. The British Journal of Psychiatry. 2000; 176: 464-7.

688 58. Gould CE, Beaudreau SA. Association between depression and anxiety on blood pressure dysregulation and 689 pulse in the Health and Retirement Study. International Journal of Geriatric Psychiatry. 2013; 28: 1045-53.

690 59. Lechin F, van der Dijs B, Orozco B, Lechin ME, Báez S, Lechin AE, Rada I, Acosta E, Arocha L, Jiménez V. 691 Plasma neurotransmitters, blood pressure, and heart rate during supine-resting, orthostasis, and moderate exercise 692 conditions in major depressed patients. Biological Psychiatry. 1995; 38: 166-73.

693 60. Kemp AH, Quintana DS, Quinn CR, Hopkinson P, Harris AW. Major depressive disorder with melancholia 694 displays robust alterations in resting state heart rate and its variability: implications for future morbidity and mortality. 695 Frontiers in Psychology. 2014; 5: 1387.

696 61. Luppino FS, de Wit LM, Bouvy PF, Stijnen T, Cuijpers P, Penninx BW, Zitman FG. Overweight, obesity, and 697 depression: a systematic review and meta-analysis of longitudinal studies. Archives of General Psychiatry. 2010; 67: $698 \quad 220-9$

699 62. Geoffroy M-C, Li L, Power C. Depressive symptoms and body mass index: co-morbidity and direction of 700 association in a British birth cohort followed over 50 years. Psychological Medicine. 2014; 44: 2641-52.

701 63. Rivenes AC, Harvey SB, Mykletun A. The relationship between abdominal fat, obesity, and common mental 702 disorders: results from the HUNT study. Journal of Psychosomatic Research. 2009; 66: 269-75.

703 64. Ho RC, Niti M, Kua EH, Ng TP. Body mass index, waist circumference, waist-hip ratio and depressive 704 symptoms in Chinese elderly: a population-based study. International Journal of Geriatric Psychiatry. 2008; 23: 401-8. 
medRxiv preprint doi: https://doi.org/10.1101/2021.02.03.21251076; this version posted June 30, 2021. The copyright holder for this preprint (which was not certified by peer review) is the author/funder, who has granted medRxiv a license to display the preprint in perpetuity.

It is made available under a CC-BY-NC-ND 4.0 International license.

705 65. Zhi T, Wang Q, Liu Z, Zhu Y, Wang Y, Shi R, Wang Z, Chu X, Wang X, Jiang X. Body mass index, waist

706 circumference and waist-hip ratio are associated with depressive symptoms in older Chinese women: results from the

707 Rugao Longevity and Ageing Study (RuLAS). Aging \& Mental Health. 2017; 21: 518-23.

708 66. De Wit LM, Van Straten A, Van Herten M, Penninx BW, Cuijpers P. Depression and body mass index, a u709 shaped association. BMC Public Health. 2009; 9: 14.

710 67. Gale C, Sayer AA, Cooper C, Dennison E, Starr J, Whalley L, Gallacher JE, Ben-Shlomo Y, Kuh D, Hardy R,

711 Craig L, Deary IJ. Factors associated with symptoms of anxiety and depression in five cohorts of community-based older

712 people: the HALCyon (Healthy Ageing across the Life Course) Programme. Psychological Medicine. 2011; 41: 2057-73.

713 68. Speed MS, Jefsen OH, Børglum AD, Speed D, Østergaard SD. Investigating the association between body fat

714 and depression via Mendelian randomization. Translational Psychiatry. 2019; 9: 1-9.

715 69. Baldofski S, Mauche N, Dogan-Sander E, Bot M, Brouwer I, Paans N, Cabout M, Gili M, van Grootheest G,

716 Hegerl U, Owens M, Roca M, Visser M, et al. Depressive symptom clusters in relation to body weight status: results

717 from two large European multi-center studies. Frontiers in Psychiatry. 2019; 10: 858.

718 70. Ul-Haq Z, Smith DJ, Nicholl BI, Cullen B, Martin D, Gill JM, Evans J, Roberts B, Deary IJ, Gallacher J,

719 Hotopf M, Craddock N, Mackay DF, et al. Gender differences in the association between adiposity and probable major

720 depression: a cross-sectional study of 140,564 UK Biobank participants. BMC Psychiatry. 2014; $14: 153$.

721 71. Wiltink J, Michal M, Wild PS, Zwiener I, Blettner M, Münzel T, Schulz A, Kirschner Y, Beutel ME.

722 Associations between depression and different measures of obesity (BMI, WC, WHtR, WHR). BMC Psychiatry. 2013;

$723 \quad 13: 223$

724 72. Mezuk B, Golden SH, Eaton WW, Lee HB. Depression and body composition among older adults. Aging \&

725 Mental Health. 2012; 16: 167-72.

726 73. Giovannini S, Macchi C, Liperoti R, Laudisio A, Coraci D, Loreti C, Vannetti F, Onder G, Padua L, Bonaccorsi

727 G. Association of body fat with health-related quality of life and depression in nonagenarians: the Mugello Study.

728 Journal of the American Medical Directors Association. 2019; 20: 564-8.

729 74. van Milligen BA, Lamers F, Guus T, Smit JH, Penninx BW. Objective physical functioning in patients with 730 depressive and/or anxiety disorders. Journal of Affective Disorders. 2011; 131: 193-9.

731 75. Spitzer C, Gläser S, Grabe HJ, Ewert R, Barnow S, Felix SB, Freyberger HJ, Völzke H, Koch B, Schäper C.

732 Mental health problems, obstructive lung disease and lung function: findings from the general population. Journal of

733 Psychosomatic Research. 2011; 71: 174-9.

734 76. Park Y, Jung JY, Kim YS, Chung KS, Song JH, Kim SY, Kim EY, Kang YA, Park MS, Chang J, Leem AY.

735 Relationship between depression and lung function in the general population in Korea: a retrospective cross-sectional

736 study. International Journal of Chronic Obstructive Pulmonary Disease. 2018; 13: 2207-13. 
medRxiv preprint doi: https://doi.org/10.1101/2021.02.03.21251076; this version posted June 30, 2021. The copyright holder for this preprint (which was not certified by peer review) is the author/funder, who has granted medRxiv a license to display the preprint in perpetuity.

It is made available under a CC-BY-NC-ND 4.0 International license.

77. Giltay EJ, Nissinen A, Giampaoli S, Zitman FG, Kromhout D. Low respiratory function increases the risk of depressive symptoms in later life in men. Psychosomatic Medicine. 2010; 72: 53-60.

78. Rosenblat J, Gregory J, Carvalho A, McIntyre R. Depression and disturbed bone metabolism: a narrative review of the epidemiological findings and postulated mechanisms. Current Molecular Medicine. 2016; 16: 165-78.

79. Wu Q, Magnus J, Liu J, Bencaz A, Hentz J. Depression and low bone mineral density: a meta-analysis of epidemiologic studies. Osteoporosis International. 2009; 20: 1309-20.

80. Williams LJ, Pasco JA, Jacka FN, Hodge JM, Kotowicz MA, Berk M. Quantitative Heel Ultrasound (QUS) measures of bone quality in association with mood and anxiety disorders. Journal of Affective Disorders. 2013; 146: $395-400$.

81. Atteritano M, Lasco A, Mazzaferro S, Macrì I, Catalano A, Santangelo A, Bagnato G, Bagnato G, Frisina N. Bone mineral density, quantitative ultrasound parameters and bone metabolism in postmenopausal women with depression. Internal and Emergency Medicine. 2013; 8: 485-91.

82. Peng L, Bi S, Liu X, Long T, Zhao Y, Li F, Yang T, Zhang C. Association between depressive symptoms and arterial stiffness: a cross-sectional study in the general Chinese population. BMJ Open. 2020; 10: e033408.

83. Seldenrijk A, van Hout HP, van Marwijk HW, de Groot E, Gort J, Rustemeijer C, Diamant M, Penninx BW. Depression, anxiety, and arterial stiffness. Biological Psychiatry. 2011; 69: 795-803.

84. Dregan A, Rayner L, Davis KA, Bakolis I, de la Torre JA, Das-Munshi J, Hatch SL, Stewart R, Hotopf M. Associations between depression, arterial stiffness, and metabolic syndrome among adults in the UK Biobank Population Study: a mediation analysis. JAMA Psychiatry. 2020; 77: 598-606.

85. Lever-van Milligen BA, Lamers F, Smit JH, Penninx BW. Six-year trajectory of objective physical function in persons with depressive and anxiety disorders. Depression and Anxiety. 2017; 34: 188-97.

86. Shah MT, Zonderman AB, Waldstein SR. Sex and age differences in the relation of depressive symptoms with blood pressure. American Journal of Hypertension. 2013; 26: 1413-20.

87. Erez HB, Weller A, Vaisman N, Kreitler S. The relationship of depression, anxiety and stress with low bone mineral density in post-menopausal women. Archives of Osteoporosis. 2012; 7: 247-55.

88. Yirmiya R, Bab I. Major depression is a risk factor for low bone mineral density: a meta-analysis. Biological Psychiatry. 2009; 66: 423-32.

89. Diem SJ, Blackwell TL, Stone KL, Yaffe K, Cauley JA, Whooley MA, Ensrud KE. Depressive symptoms and rates of bone loss at the hip in older women. Journal of the American Geriatrics Society. 2007; 55: 824-31.

90. Diem S, Harrison S, Haney E, Cauley J, Stone K, Orwoll E, Ensrud K. Depressive symptoms and rates of bone loss at the hip in older men. Osteoporosis International. 2013; 24: 111-9. 
medRxiv preprint doi: https://doi.org/10.1101/2021.02.03.21251076; this version posted June 30, 2021. The copyright holder for this preprint (which was not certified by peer review) is the author/funder, who has granted medRxiv a license to display the preprint in perpetuity.

It is made available under a CC-BY-NC-ND 4.0 International license.

768 91. Cizza G, Mistry S, Nguyen VT, Eskandari F, Martinez P, Torvik S, Reynolds JC, Gold PW, Sinai N, Csako G.

769 Do premenopausal women with major depression have low bone mineral density? A 36-month prospective study. PloS

770 One. $2012 ; 7:$ e40894.

771 92. Mezuk B, Eaton WW, Golden SH, Wand G, Lee HB. Depression, antidepressants, and bone mineral density in a 772 population-based cohort. The Journals of Gerontology Series A: Biological Sciences and Medical Sciences. 2008; 63:

$773 \quad 1410-5$

774 93. Pinto E. Blood pressure and ageing. Postgraduate Medical Journal. 2007; 83: 109-14.

775 94. Hübel C, Gaspar HA, Coleman JR, Hanscombe KB, Purves K, Prokopenko I, Graff M, Ngwa JS, Workalemahu

776 T, O’Reilly PF, Bulik CM, Breen G. Genetic correlations of psychiatric traits with body composition and glycemic traits 777 are sex-and age-dependent. Nature Communications. 2019; 10: 1-12.

778 95. Bäckman K, Joas E, Falk H, Mitnitski A, Rockwood K, Skoog I. Changes in the lethality of frailty over 30 779 years: evidence from two cohorts of 70-year-olds in Gothenburg Sweden. The Journals of Gerontology: Series A. 2017; $780 \quad 72: 945-50$

781 96. Yu R, Wong M, Chong K, Chang B, Lum C, Auyeung T, Lee J, Lee R, Woo J. Trajectories of frailty among 782 Chinese older people in Hong Kong between 2001 and 2012: an age-period-cohort analysis. Age and Ageing. 2018; 47: $783 \quad 254-61$.

$78497 . \quad$ Yang Y, Lee LC. Dynamics and heterogeneity in the process of human frailty and aging: evidence from the US 785 older adult population. Journals of Gerontology Series B: Psychological Sciences and Social Sciences. $2010 ; 65: 246-55$. 786 98. Glanville KP, Coleman JR, Howard DM, Pain O, Hanscombe KB, Jermy B, Arathimos R, Hübel C, Breen G, 787 O'Reilly PF, Lewis CM. Multiple measures of depression to enhance validity of Major Depressive Disorder in the UK 788 Biobank. BJPsych Open. 2021; 7: e44.

789 99. Davis K, Hotopf M. Mental health phenotyping in UK Biobank. Progress in Neurology and Psychiatry. 2019; $790 \quad 23: 4-7$

791 100. Davis KA, Cullen B, Adams M, Brailean A, Breen G, Coleman JR, Dregan A, Gaspar HA, Hübel C, Lee W, 792 McIntosh AM, Nolan J, Pearsall R, et al. Indicators of mental disorders in UK Biobank-A comparison of approaches. 793 International Journal of Methods in Psychiatric Research. 2019; 28: e1796.

794 101. Fry A, Littlejohns TJ, Sudlow C, Doherty N, Adamska L, Sprosen T, Collins R, Allen NE. Comparison of 795 sociodemographic and health-related characteristics of UK Biobank participants with those of the general population. 796 American Journal of Epidemiology. 2017; 186: 1026-34.

797 102. Battya GD, Galec CR, Kivimäkia M, Dearyd IJ, Belle S. Comparison of risk factor associations in UK Biobank 798 against representative, general population based studies with conventional response rates: prospective cohort study and 799 individual participant meta-analysis. The BMJ. 2020; 368: m131. 
medRxiv preprint doi: https://doi.org/10.1101/2021.02.03.21251076; this version posted June 30, 2021. The copyright holder for this preprint (which was not certified by peer review) is the author/funder, who has granted medRxiv a license to display the preprint in perpetuity. It is made available under a CC-BY-NC-ND 4.0 International license.

103. Knudsen AK, Hotopf M, Skogen JC, Øverland S, Mykletun A. The health status of nonparticipants in a population-based health study: the Hordaland Health Study. American Journal of Epidemiology. 2010; 172: $1306-14$. 104. Ansai JH, Rebelatto JR. Effect of two physical exercise protocols on cognition and depressive symptoms in oldest-old people: a randomized controlled trial. Geriatrics \& Gerontology International. 2015; 15: 1127-34.

105. Mutz J, Roscoe CJ, Lewis CM. Exploring health in the UK Biobank: associations with sociodemographic characteristics, psychosocial factors, lifestyle and environmental exposures. medRxiv. 2021.

106. Bycroft C, Freeman C, Petkova D, Band G, Elliott LT, Sharp K, Motyer A, Vukcevic D, Delaneau O, O’Connell J, Cortes A, Welsh S, Young A, et al. The UK Biobank resource with deep phenotyping and genomic data. Nature. 2018; 562: 203-9.

107. Davis KA, Coleman JR, Adams M, Allen N, Breen G, Cullen B, Dickens C, Fox E, Graham N, Holliday J, Howard LM, John A, Lee W, et al. Mental health in UK Biobank-development, implementation and results from an online questionnaire completed by 157366 participants: a reanalysis. BJPsych Open. 2020; 6: E18.

108. Fabbri C, Hagenaars SP, John C, Williams AT, Shrine N, Moles L, Hanscombe KB, Serretti A, Shepherd DJ, Free RS, Wain LV, Tobin MD, Lewis CM. Genetic and clinical characteristics of treatment-resistant depression using primary care records in two UK cohorts. Molecular Psychiatry. 2021.

109. Smith DJ, Nicholl BI, Cullen B, Martin D, Ul-Haq Z, Evans J, Gill JM, Roberts B, Gallacher J, Mackay D, Hotopf M, Deary I, Craddock N, et al. Prevalence and characteristics of probable major depression and bipolar disorder within UK Biobank: cross-sectional study of 172,751 participants. PloS One. 2013; 8: e75362.

110. Firth JA, Smith L, Sarris J, Vancampfort D, Schuch F, Carvalho AF, Solmi M, Yung AR, Stubbs B, Firth J. Handgrip strength is associated with hippocampal volume and white matter hyperintensities in major depression and healthy controls: a UK Biobank study. Psychosomatic Medicine. 2020; 82: 39-46.

111. Hanlon P, Nicholl BI, Jani BD, Lee D, McQueenie R, Mair FS. Frailty and pre-frailty in middle-aged and older adults and its association with multimorbidity and mortality: a prospective analysis of 493737 UK Biobank participants. The Lancet Public Health. 2018; 3: e323-e32.

112. Doiron D, de Hoogh K, Probst-Hensch N, Fortier I, Cai Y, De Matteis S, Hansell AL. Air pollution, lung function and COPD: results from the population-based UK Biobank study. European Respiratory Journal. 2019; 54: 1802140.

113. Said MA, Eppinga RN, Lipsic E, Verweij N, van der Harst P. Relationship of arterial stiffness index and pulse pressure with cardiovascular disease and mortality. Journal of the American Heart Association. 2018; 7: e007621.

114. Millasseau SC, Kelly R, Ritter J, Chowienczyk P. Determination of age-related increases in large artery stiffness by digital pulse contour analysis. Clinical Science. 2002; 103: 371-7.

115. Wood SN. Generalized additive models: an introduction with R. 2017. 
medRxiv preprint doi: https://doi.org/10.1101/2021.02.03.21251076; this version posted June 30, 2021. The copyright holder for this preprint (which was not certified by peer review) is the author/funder, who has granted medRxiv a license to display the preprint in perpetuity. It is made available under a CC-BY-NC-ND 4.0 International license .

832 116. Benjamini Y, Hochberg Y. Controlling the false discovery rate: a practical and powerful approach to multiple 833 testing. Journal of the Royal Statistical Society: Series B (Methodological). 1995; 57: 289-300. 
medRxiv preprint doi: https://doi.org/10.1101/2021.02.03.21251076; this version posted June 30, 2021. The copyright holder for this preprint

(which was not certified by peer review) is the author/funder, who has granted medRxiv a license to display the preprint in perpetuity.

It is made available under a CC-BY-NC-ND 4.0 International license .

\section{Figure legends}

835

836 Figure 1. Flowchart of study population. The main dataset included hand-grip strength, blood pressure, pulse rate and measures of body composition.

Figure 2. Generalised additive models of age-related changes in physiological measures in females with lifetime depression and healthy controls. The solid lines represent physiological measures against smoothing functions of age. The shaded areas correspond to approximate $95 \%$ confidence intervals $\left( \pm 2 \times\right.$ standard error). $\mathrm{FEV}_{1}=$ forced expiratory volume in one second; $\mathrm{FVC}=$ forced vital capacity.

Figure 3. Generalised additive models of age-related changes in physiological measures in males with lifetime depression and healthy controls. The solid lines represent physiological measures against smoothing functions of age. The shaded areas correspond to approximate $95 \%$ confidence intervals $( \pm 2 \times$ standard error $)$. FEV ${ }_{1}=$ forced expiratory volume in one second; $\mathrm{FVC}=$ forced vital capacity.

Figure 4. Difference smooths comparing age-related changes in physiological measures of females with lifetime depression to healthy controls. The shaded areas correspond to approximate $95 \%$ confidence intervals $( \pm 2 \times$ standard error). Negative values on the y-axes correspond to lower values in females with lifetime depression compared to healthy controls. The horizontal lines represent no difference between female cases and controls. $\mathrm{FEV}_{1}=$ forced expiratory volume in one second; FVC = forced vital capacity; Bonf. = Bonferroni; $\mathrm{BH}=$ Benjamini \& Hochberg.

Figure 5. Difference smooths comparing age-related changes in physiological measures of males with lifetime depression to healthy controls. The shaded areas correspond to approximate $95 \%$ confidence intervals $( \pm 2 \times$ standard error). Negative values on the y-axes correspond to lower values in males with lifetime depression compared to healthy controls. The horizontal lines represent no difference between male cases and controls. FEV $1=$ forced expiratory volume in one second; FVC = forced vital capacity; Bonf. = Bonferroni; $\mathrm{BH}=$ Benjamini \& Hochberg. 
medRxiv preprint doi: https://doi.org/10.1101/2021.02.03.21251076; this version posted June 30, 2021. The copyright holder for this preprint (which was not certified by peer review) is the author/funder, who has granted medRxiv a license to display the preprint in perpetuity.

It is made available under a CC-BY-NC-ND 4.0 International license.

\section{Tables}

861

Table 1. Physiological measures

\begin{tabular}{|c|c|c|c|c|c|}
\hline & \multirow[b]{2}{*}{$\begin{array}{c}\text { Overall } \\
(\mathrm{N}=502521)\end{array}$} & \multicolumn{2}{|c|}{ Female } & \multicolumn{2}{|c|}{ Male } \\
\hline & & $\begin{array}{l}\text { Healthy control } \\
(\mathrm{N}=123842)\end{array}$ & $\begin{array}{l}\text { Depression } \\
(\mathrm{N}=56276)\end{array}$ & $\begin{array}{l}\text { Healthy control } \\
(\mathrm{N}=131212)\end{array}$ & $\begin{array}{l}\text { Depression } \\
(\mathrm{N}=31063)\end{array}$ \\
\hline \multicolumn{6}{|c|}{ Hand-grip strength } \\
\hline Mean (SD) & $31.77(11.34)$ & $25.10(6.46)$ & $24.73(6.67)$ & $41.34(9.09)$ & $40.37(9.37)$ \\
\hline Missing & 3203 & & & & \\
\hline \multicolumn{6}{|c|}{ Systolic blood pressure } \\
\hline Mean (SD) & $137.87(18.65)$ & $135.07(19.20)$ & $132.32(18.28)$ & $141.11(17.38)$ & $139.02(16.78)$ \\
\hline Missing & 1325 & & & & \\
\hline \multicolumn{6}{|c|}{ Diastolic blood pressure } \\
\hline Mean (SD) & $82.26(10.15)$ & $80.63(9.98)$ & $80.26(9.93)$ & $84.19(9.96)$ & $83.78(10.02)$ \\
\hline Missing & 1323 & & & & \\
\hline \multicolumn{6}{|l|}{ Pulse rate } \\
\hline Mean (SD) & $69.42(11.26)$ & $69.83(10.38)$ & $70.05(10.52)$ & $67.74(11.59)$ & $68.70(11.99)$ \\
\hline Missing & 1323 & & & & \\
\hline \multicolumn{6}{|c|}{ Body mass index } \\
\hline Mean (SD) & $27.43(4.80)$ & $26.63(4.86)$ & $27.35(5.39)$ & $27.62(4.01)$ & $28.08(4.45)$ \\
\hline Missing & 3105 & & & & \\
\hline \multicolumn{6}{|c|}{ Body fat percentage } \\
\hline Mean (SD) & $31.45(8.55)$ & $35.98(6.77)$ & $36.87(7.02)$ & $24.93(5.63)$ & $25.55(5.88)$ \\
\hline Missing & 10408 & & & & \\
\hline \multicolumn{6}{|l|}{ Fat mass } \\
\hline Mean (SD) & $24.86(9.57)$ & $26.12(9.55)$ & $27.67(10.60)$ & $21.85(7.87)$ & $22.88(8.71)$ \\
\hline Missing & 10973 & & & & \\
\hline \multicolumn{6}{|c|}{ Fat-free mass } \\
\hline Mean (SD) & $53.22(11.50)$ & $44.43(4.85)$ & $45.05(5.17)$ & $63.74(7.61)$ & $64.25(7.93)$ \\
\hline Missing & 10176 & & & & \\
\hline \multicolumn{6}{|c|}{ Waist-hip ratio } \\
\hline Mean (SD) & $0.87(0.09)$ & $0.81(0.07)$ & $0.82(0.07)$ & $0.93(0.06)$ & $0.94(0.07)$ \\
\hline \multirow[t]{2}{*}{ Missing } & 2265 & & & & \\
\hline & & $\mathrm{N}=43133$ & $\mathrm{~N}=19146$ & $\mathrm{~N}=52359$ & $\mathrm{~N}=12177$ \\
\hline \multicolumn{6}{|c|}{ Peak expiratory flow } \\
\hline Mean (SD) & $407.82(130.78)$ & 355.08 (76.97) & $359.35(76.98)$ & $511.67(115.38)$ & $509.05(117.30)$ \\
\hline \multirow{2}{*}{\multicolumn{6}{|c|}{ Forced expiratory volume 1s }} \\
\hline & & & & & \\
\hline Mean (SD) & $2.85(0.78)$ & $2.50(0.53)$ & $2.53(0.53)$ & $3.45(0.73)$ & $3.43(0.75)$ \\
\hline Missing & 149197 & & & & \\
\hline \multicolumn{6}{|c|}{ Forced vital capacity } \\
\hline Mean (SD) & $3.78(0.98)$ & $3.28(0.64)$ & $3.31(0.64)$ & $4.59(0.88)$ & $4.57(0.90)$ \\
\hline Missing & 149197 & & & & \\
\hline \multicolumn{6}{|l|}{ FEV 1 / FVC } \\
\hline Mean (SD) & $0.75(0.07)$ & $0.76(0.06)$ & $0.76(0.06)$ & $0.75(0.07)$ & $0.75(0.07)$ \\
\hline \multirow[t]{2}{*}{ Missing } & 149197 & & & & \\
\hline & & $\mathrm{N}=85994$ & $\mathrm{~N}=31736$ & $\mathrm{~N}=89790$ & $\mathrm{~N}=17285$ \\
\hline \multicolumn{6}{|c|}{ Heel bone mineral density } \\
\hline Mean (SD) & $0.54(0.14)$ & $0.52(0.12)$ & $0.52(0.12)$ & $0.58(0.15)$ & $0.57(0.15)$ \\
\hline \multirow[t]{2}{*}{ Missing } & 180831 & & & & \\
\hline & & $\mathrm{N}=38592$ & $\mathrm{~N}=25073$ & $\mathrm{~N}=42889$ & $\mathrm{~N}=14289$ \\
\hline \multicolumn{6}{|c|}{ Arterial stiffness } \\
\hline Mean (SD) & $9.34(4.05)$ & $8.70(4.41)$ & $8.71(3.27)$ & $9.91(4.27)$ & $9.97(3.30)$ \\
\hline Missing & 332721 & & & & \\
\hline
\end{tabular}

Note: $\mathrm{SD}=$ standard deviation; $\mathrm{FEV}_{1}=$ forced expiratory volume in one second; $\mathrm{FVC}=$ forced vital capacity. 
medRxiv preprint doi: https://doi.org/10.1101/2021.02.03.21251076; this version posted June 30, 2021. The copyright holder for this preprint

(which was not certified by peer review) is the author/funder, who has granted medRxiv a license to display the preprint in perpetuity.

It is made available under a CC-BY-NC-ND 4.0 International license .

Table 2. Sex differences in physiological measures (females compared to males)

\begin{tabular}{lccc}
\hline Variable & SMD & \multicolumn{2}{c}{$95 \%$ CI } \\
\hline Hand-grip strength & -2.051 & -2.060 & -2.043 \\
Systolic blood pressure & -0.358 & -0.364 & -0.351 \\
Diastolic blood pressure & -0.361 & -0.368 & -0.354 \\
Pulse rate & 0.179 & 0.172 & 0.186 \\
Body mass index & -0.185 & -0.191 & -0.178 \\
Body fat percentage & 1.771 & 1.763 & 1.779 \\
Fat mass & 0.502 & 0.496 & 0.509 \\
Fat-free mass & -3.006 & -3.016 & -2.997 \\
Waist-hip ratio & -1.775 & -1.782 & -1.767 \\
Peak expiratory flow & -1.569 & -1.582 & -1.557 \\
Forced expiratory volume 1s & -1.460 & -1.473 & -1.448 \\
Forced vital capacity & -1.674 & -1.687 & -1.661 \\
FEV 1 FVC & 0.165 & 0.154 & 0.176 \\
Heel bone mineral density & -0.397 & -0.405 & -0.388 \\
Arterial stiffness & -0.304 & -0.315 & -0.292 \\
\hline
\end{tabular}

Note: $\mathrm{SMD}=$ standardised mean difference; $\mathrm{CI}=$ confidence interval; $\mathrm{FEV}_{1}=$ forced

expiratory volume in one second; FVC $=$ forced vital capacity. All Bonferroni-adjusted $p$ values for Welch's t-test $<0.001$. Negative values correspond to lower values in females. 
medRxiv preprint doi: https://doi.org/10.1101/2021.02.03.21251076; this version posted June 30, 2021. The copyright holder for this preprint (which was not certified by peer review) is the author/funder, who has granted medRxiv a license to display the preprint in perpetuity. It is made available under a CC-BY-NC-ND 4.0 International license .

Table 3. Differences in physiological measures between individuals with lifetime depression and healthy controls

\begin{tabular}{|c|c|c|c|c|c|c|c|c|c|c|}
\hline \multirow{3}{*}{$\begin{array}{l}\text { Variable } \\
\text { Hand-grip strength }\end{array}$} & \multicolumn{5}{|c|}{ Female } & \multicolumn{5}{|c|}{ Male } \\
\hline & \multirow{2}{*}{$\begin{array}{l}\text { SMD } \\
-0.056\end{array}$} & \multicolumn{2}{|c|}{$95 \% \mathrm{CI}$} & \multirow{2}{*}{$\begin{array}{l}p_{\text {Bonf. }} \\
<0.001\end{array}$} & \multirow{2}{*}{$\begin{array}{c}p_{\mathrm{BH}} \\
<0.001\end{array}$} & \multirow{2}{*}{$\begin{array}{l}\text { SMD } \\
-0.106\end{array}$} & \multicolumn{2}{|c|}{$95 \% \mathrm{CI}$} & \multirow{2}{*}{$\begin{array}{c}p_{\text {Bonf. }} \\
<0.001\end{array}$} & \multirow{2}{*}{$\begin{array}{r}p_{\mathrm{BH}} \\
<0.001\end{array}$} \\
\hline & & -0.066 & -0.046 & & & & -0.118 & -0.093 & & \\
\hline Systolic blood pressure & -0.145 & -0.155 & -0.135 & $<0.001$ & $<0.001$ & -0.121 & -0.133 & -0.108 & $<0.001$ & $<0.001$ \\
\hline Diastolic blood pressure & -0.037 & -0.047 & -0.028 & $<0.001$ & $<0.001$ & -0.041 & -0.053 & -0.028 & $<0.001$ & $<0.001$ \\
\hline Pulse rate & 0.022 & 0.012 & 0.032 & $<0.001$ & $<0.001$ & 0.083 & 0.070 & 0.095 & $<0.001$ & $<0.001$ \\
\hline Body mass index & 0.144 & 0.134 & 0.154 & $<0.001$ & $<0.001$ & 0.112 & 0.100 & 0.124 & $<0.001$ & $<0.001$ \\
\hline Body fat percentage & 0.129 & 0.119 & 0.139 & $<0.001$ & $<0.001$ & 0.111 & 0.098 & 0.123 & $<0.001$ & $<0.001$ \\
\hline Fat mass & 0.156 & 0.146 & 0.166 & $<0.001$ & $<0.001$ & 0.129 & 0.117 & 0.141 & $<0.001$ & $<0.001$ \\
\hline Fat-free mass & 0.124 & 0.114 & 0.134 & $<0.001$ & $<0.001$ & 0.066 & 0.053 & 0.078 & $<0.001$ & $<0.001$ \\
\hline Waist-hip ratio & 0.090 & 0.080 & 0.100 & $<0.001$ & $<0.001$ & 0.138 & 0.126 & 0.151 & $<0.001$ & $<0.001$ \\
\hline Peak expiratory flow & 0.055 & 0.038 & 0.072 & $<0.001$ & $<0.001$ & -0.023 & -0.042 & -0.003 & 0.382 & 0.032 \\
\hline Forced expiratory volume $1 \mathrm{~s}$ & 0.051 & 0.034 & 0.068 & $<0.001$ & $<0.001$ & -0.024 & -0.044 & -0.005 & 0.241 & 0.022 \\
\hline Forced vital capacity & 0.046 & 0.029 & 0.063 & $<0.001$ & $<0.001$ & -0.022 & -0.042 & -0.003 & 0.421 & 0.032 \\
\hline $\mathrm{FEV}_{1} / \mathrm{FVC}$ & 0.018 & 0.001 & 0.035 & 0.569 & 0.044 & -0.011 & -0.031 & 0.009 & $>0.999$ & 0.276 \\
\hline Heel bone mineral density & 0.013 & -0.0001 & 0.026 & 0.789 & 0.056 & -0.077 & -0.093 & -0.061 & $<0.001$ & $<0.001$ \\
\hline Arterial stiffness & 0.004 & -0.012 & 0.020 & $>0.999$ & 0.571 & 0.015 & -0.004 & 0.034 & $>0.999$ & 0.078 \\
\hline
\end{tabular}

Note: $\mathrm{SMD}=$ standardised mean difference; $\mathrm{CI}=$ confidence interval; Bonf. $=$ Bonferroni; $\mathrm{BH}=$ Benjamini \& Hochberg; $\mathrm{FEV} \mathrm{H}_{1}=$ forced expiratory 864 volume in one second; FVC = forced vital capacity. $P$-values for Welch's t-test. Negative values correspond to lower values in depression cases. 


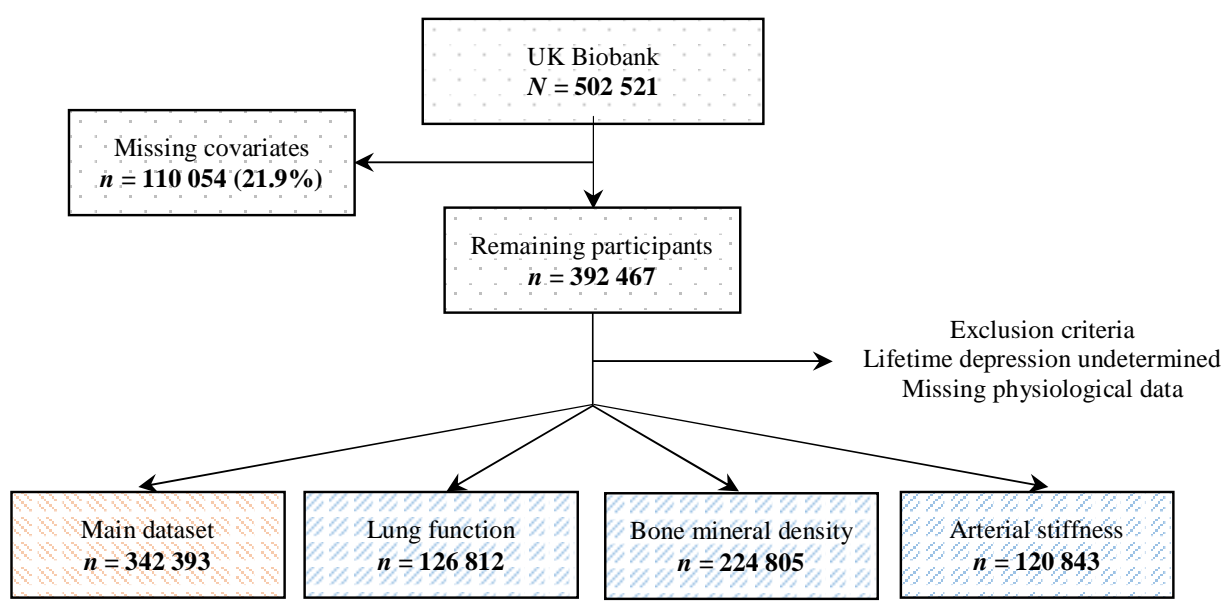



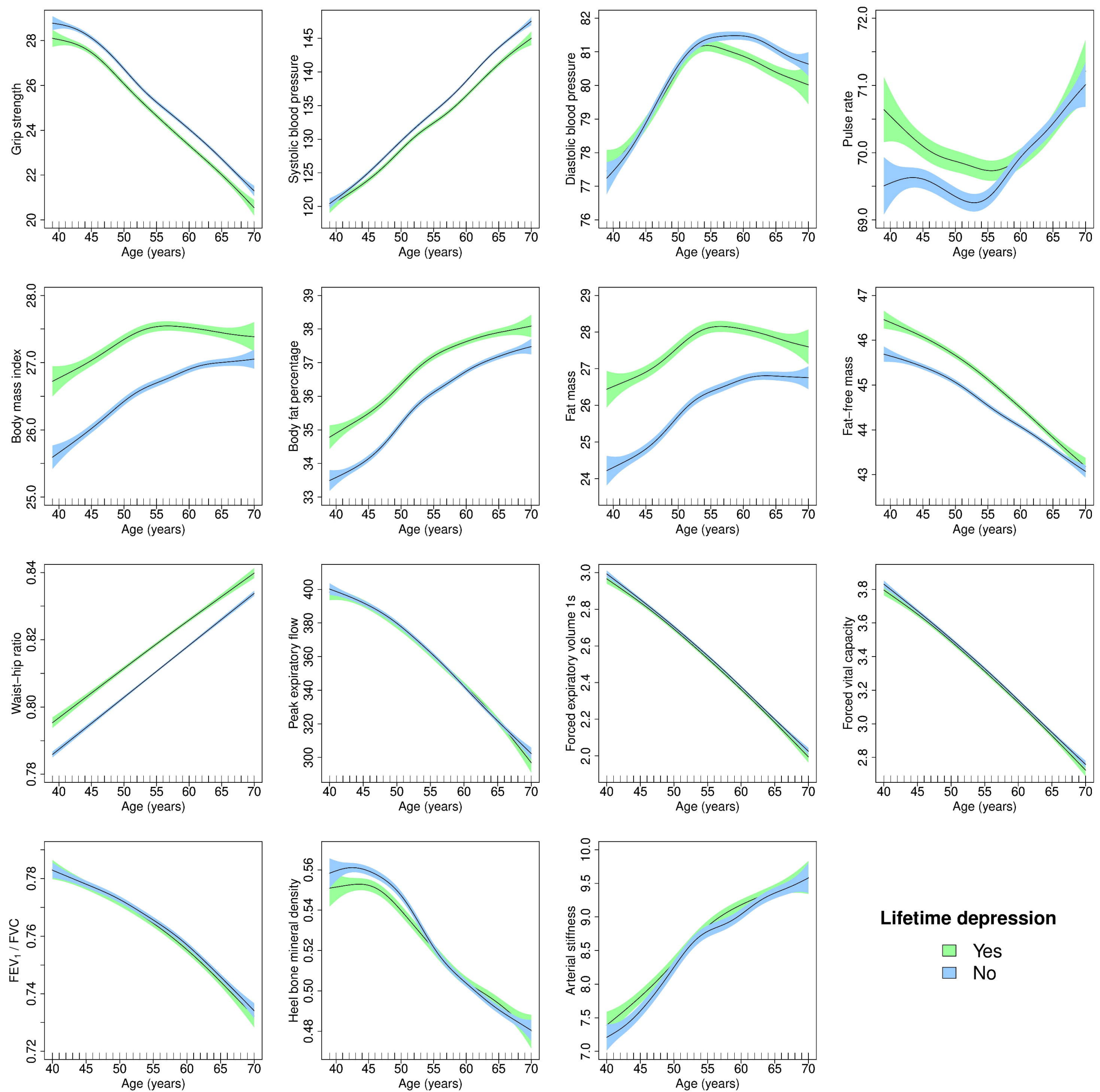

\section{Lifetime depression}

$\square$ Yes

No 

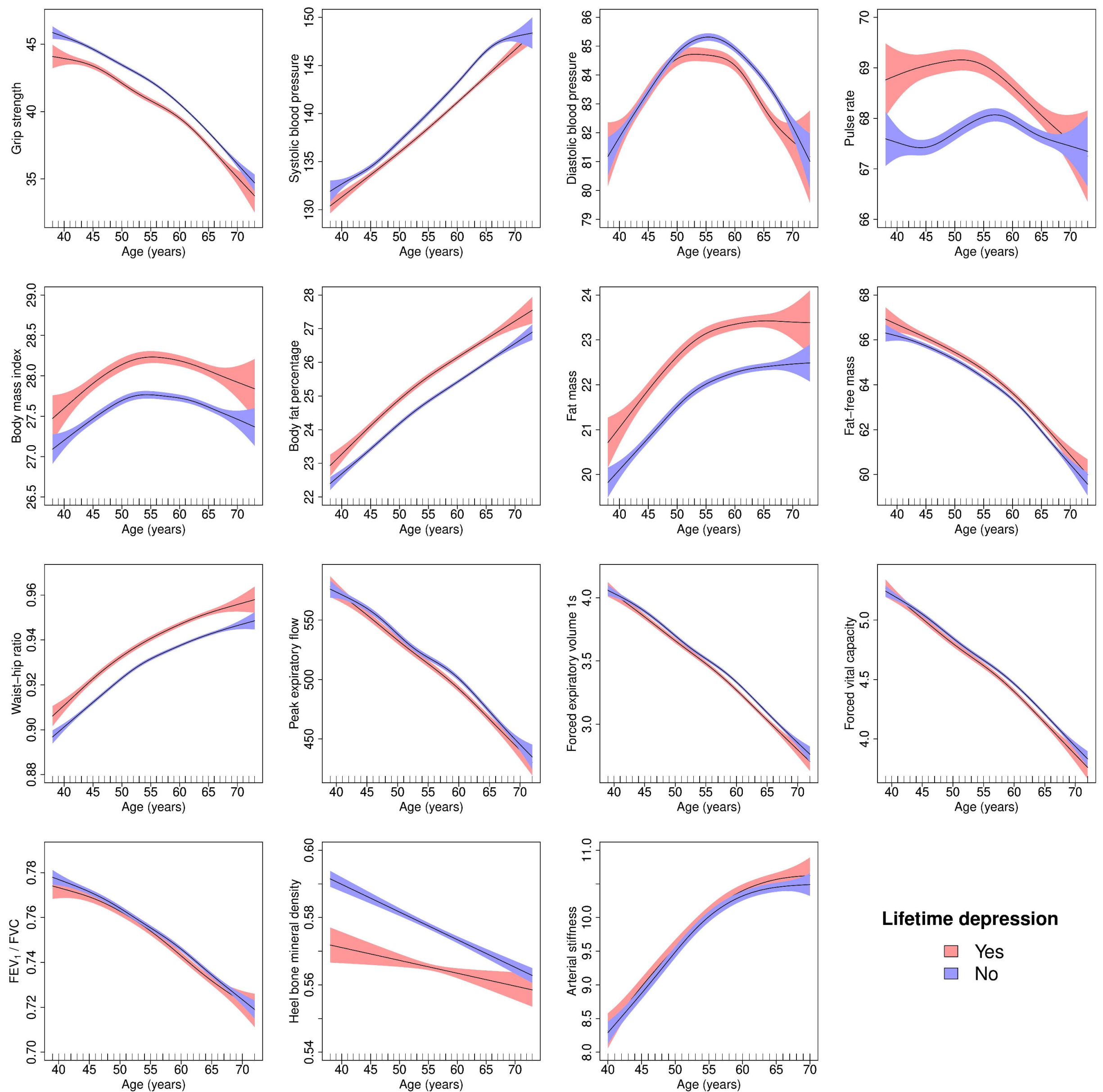

\section{Lifetime depression}

$\square$ Yes

$\square$ No 
